\title{
3. PRIMARY MINERALOGY OF LEG 115 BASALTS ${ }^{1}$
}

\author{
Martin R. Fisk ${ }^{2}$ and Katherine J. Howard ${ }^{2}$
}

\begin{abstract}
Basement rocks were recovered at four sites on Leg 115 along the Réunion hotspot track in the western Indian Ocean. Plate tectonic reconstructions indicate that the drilled structures formed in three different volcanic environments. Sites 706 and 713 from the eastern side of the Saya de Malha Bank and the northern end of the Chagos Bank, respectively, are on a large volcanic platform analogous to Iceland on the Mid-Atlantic Ridge. Lavas at Site 707 on the northwestern side of the Saya de Malha Bank erupted during the early stages of rifting of the Seychelles from India. Basalts from Site 715 were erupted onto an isolated oceanic island that was distant from ocean ridges and continents much as Réunion Island is today.

Many of the rocks were examined in thin section and found to be primarily augite-plagioclase basalts with minor olivine and rare opaque oxides. Site 715 is unusual in that it contains a variety of basalts including olivine-rich and aphyric Fe-Ti basalts. At each of the four sites the rocks were grouped into chemical types (units) on the basis of shipboard bulk-rock analyses and at least one thin section from each chemical unit was analyzed by electron microprobe. The plagioclase and augite chemistry reflects the bulk-rock chemistry and, in general, these minerals were in equilibrium with their host magmas at the time the basalts were quenched. Olivine was rarely preserved, but where it is still present it also appears to have crystallized in equilibrium with the host magma. At three of the drill sites plagioclase phenocrysts or megacrysts that crystallized from a primitive magma are also present. The one site (715) that does not contain these primitive plagioclase phenocrysts is also the site that appears to have been influenced the least by oceanridge or Deccan-type magmas. Site 715 , furthermore, has a mineralogy that is dominated by olivine as compared with the plagioclase-rich lavas of the other sites.
\end{abstract}

\section{INTRODUCTION}

The Réunion hotspot track in the western Indian Ocean extends from the volcanically active island of Réunion through the deeply eroded volcanic Island of Mauritius, the Nazareth and Saya de Malha banks, and the Chagos-Maldive-Laccadive islands to the Deccan Traps, 5,000 km from Réunion (Fig. 1). The age progression of these features has now been established (Duncan, this volume; Duncan and Hargraves, this volume) and is shown in Figure 1.

The oldest known basalts from the hotspot track (Deccan Traps) have been extensively studied (Cox and Hawkesworth, 1985; Beane et al., 1986; Dewey and Lightfoot, 1986), as have those from the young end of the hotspot (Baxter, 1972; Upton and Wadsworth, 1972; Fisk et al., 1988). Until Leg 115, however, no samples from the intermediate-age volcanoes were available. Basalts from the Deccan Traps usually have more than 48 $\mathrm{wt} \% \mathrm{SiO}_{2}$ and about $3 \mathrm{wt} \%$ total alkalis and are considered to be tholeiites (Macdonald and Katsura, 1964), whereas the basalts of Réunion Island are transitional between tholeiites and alkali basalts (Fig. 2). Preliminary major and trace element chemistry of selected lavas from all four sites (Backman, Duncan, et al., 1988; Fisk et al., 1989) show that they range in composition from primitive basalts to evolved Fe-Ti-rich basalts (Fig. 3A) and that tholeiites, transitional basalts, and alkali basalts are represented (Fig. 3B). These basalts cover nearly the same compositional range as the Réunion and Deccan lavas, combined. Extremely differentiated silicic or alkalic lavas that are commonly found in the waning stages of volcanism on oceanic islands (including Réunion) were not recovered at any of the sites.

\footnotetext{
${ }^{1}$ Duncan, R. A., Backman, J., Peterson, L. C., et al., 1990. Proc. ODP, Sci. Results, 115: College Station, TX (Ocean Drilling Program).

2 College of Oceanography, Oregon State University, Corvallis, OR 97331-5503,
}

Therefore, the recovered lavas at Sites 706,713 , and 715 represent the main shield-building stage of volcanism with tholeiitic to transitional chemistry. The lavas from Site 707 are basalts that are related to the rifting of the Seychelles platform from India during the waning stages of Deccan flood basalt activity. This relationship is inferred from the age of the basalts (64 Ma) and the plate reconstruction around the northwest Indian Ocean (Duncan, this volume).

Lavas along the Réunion hotspot track contain the usual suite of minerals found in basalts (olivine, plagioclase feldspar, and augite), but the proportions of these minerals are variable. Réunion and Deccan lavas are dominated by olivine phenocrysts, followed in abundance by plagioclase (Upton and Wadsworth, 1972; Beane et al., 1986), and the Leg 115 lavas are plagioclasedominated, followed in abundance by augite (Backman, Duncan, et al., 1988). Olivine is present in many of the Leg 115 samples, but usually is less abundant than either plagioclase or augite. The mineralogical differences between basalts may be caused by small differences in bulk chemical composition of the magmas or by different physical conditions and kinetic processes during crystallization. In an attempt to understand the differences in mineralogy along the Réunion hotspot track, we made a detailed examination of the mineral chemistry of basalts from the four sites from Leg 115 that recovered basaltic basement.

At each site, lithologic units (flows) were identified aboard ship based on glassy or vesicular contacts and on the presence of interflow sediment. Additional flows were identified by changes in texture, mineralogy and color. The number of flows varied from 5 at Site 707 (77.4 m penetration) to 35 at Site $713(63.2 \mathrm{~m}$ of basalt penetration). These flows were grouped into chemical units on the basis of shipboard whole-rock analyses. In spite of the diversity of flows, only three or four chemical units were identified at each site. These chemical units and their mineral chemistry are the subject of this report. (To avoid confusion, the term "unit" refers to a chemical unit and the term "flow" refers to the lithologic unit. The location of analyzed thin sections within chemical and lithologic units is shown in the Appendix.) 


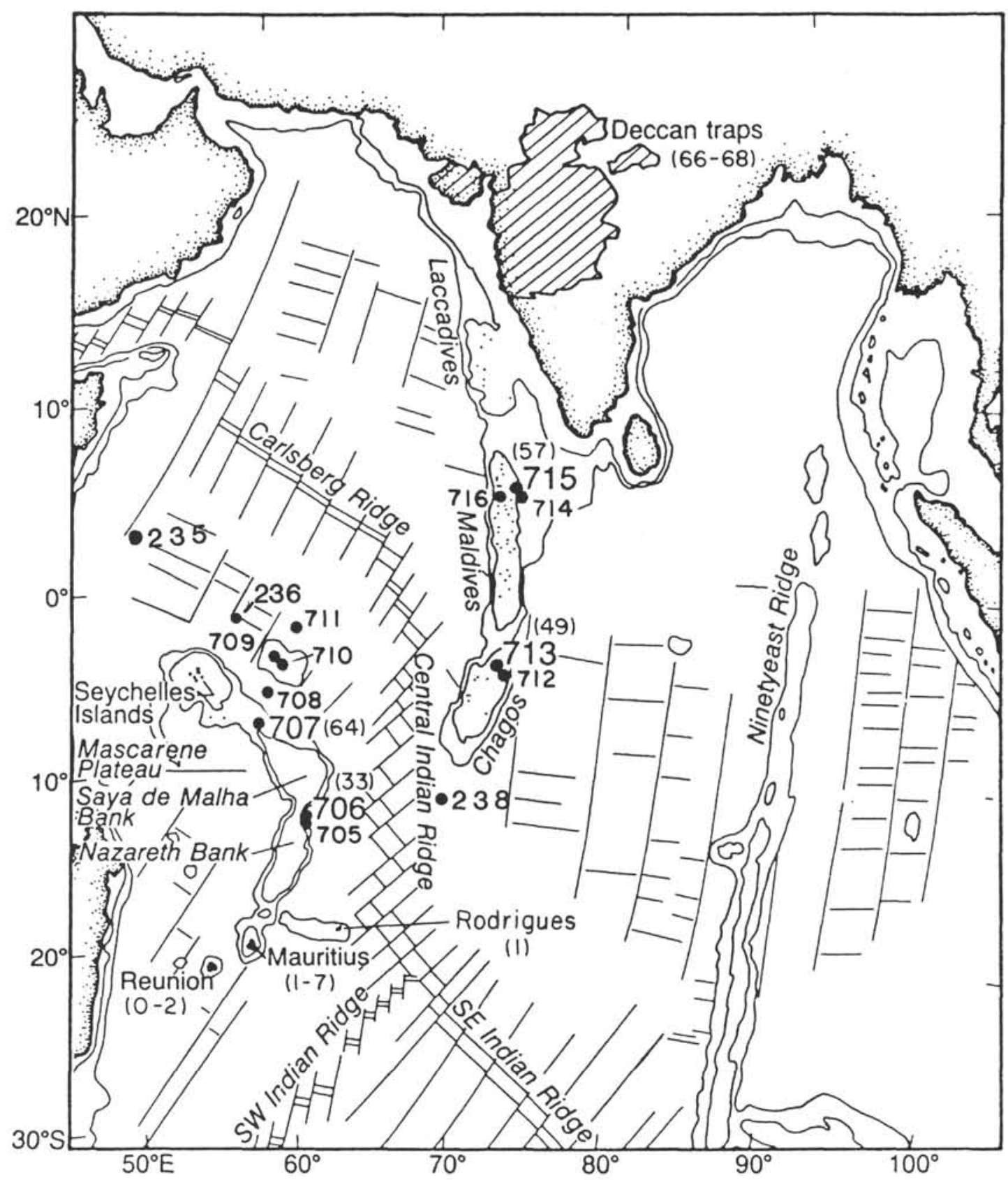

Figure 1. Map of the Indian Ocean showing the sites drilled during Leg 115. Sites 706, 707, 713, and 715 recovered basaltic basement; the age of the basement at these four locations is given in m.y. Basalts that were produced by the Réunion hotspot also include Réunion and Mauritius islands and the Deccan Traps; the ages of these basalts are also given. DSDP Leg 24 drilled three holes to basement in this area, and the position of these three holes are given (Sites 235,236 , and 238 ).

\section{METHODS}

Shipboard descriptions of the recovered samples were carried out by six petrologists as the cores were split and labeled. Polished thin sections were prepared from many of the flows and these were examined on board with petrographic microscopes to estimate modal abundances of phenocrysts, groundmass minerals and alteration (Backman, Duncan, et al., 1988). Samples for shipboard chemical analysis were carefully selected to be representative of the flows from which they came. Areas of heavy alteration were avoided but alteration or phenocrysts were not me- chanically removed from the samples before they were crushed and prepared for analysis.

The flows were grouped into chemical units on the basis of downcore major and trace element variation. Examples of the chemical variation that were used to establish chemical units at each site are given in Figure 4. (Details of the major and trace element chemistry are given in Backman, Duncan, et al. (1988), and Fisk et al. (1989). The divisions between chemical units agree closely with divisions between lithologic units determined from hand specimens and petrographic examination of the basalts (Backman, Duncan, et al., 1988). Chemical unit 3 at Site 


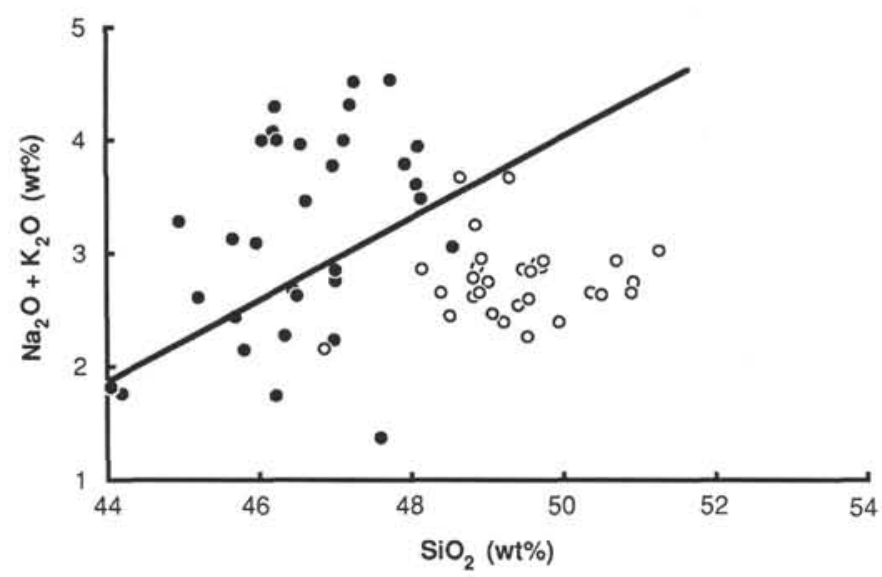

Figure 2. Silica-alkali diagram for Deccan (open circles; Cox and Hawkesworth, 1985) and Réunion lavas (filled circles; Fisk et al., 1988). The line divides the alkali and tholeiite basalt fields of Hawaii (Macdonald and Katsura, 1964).
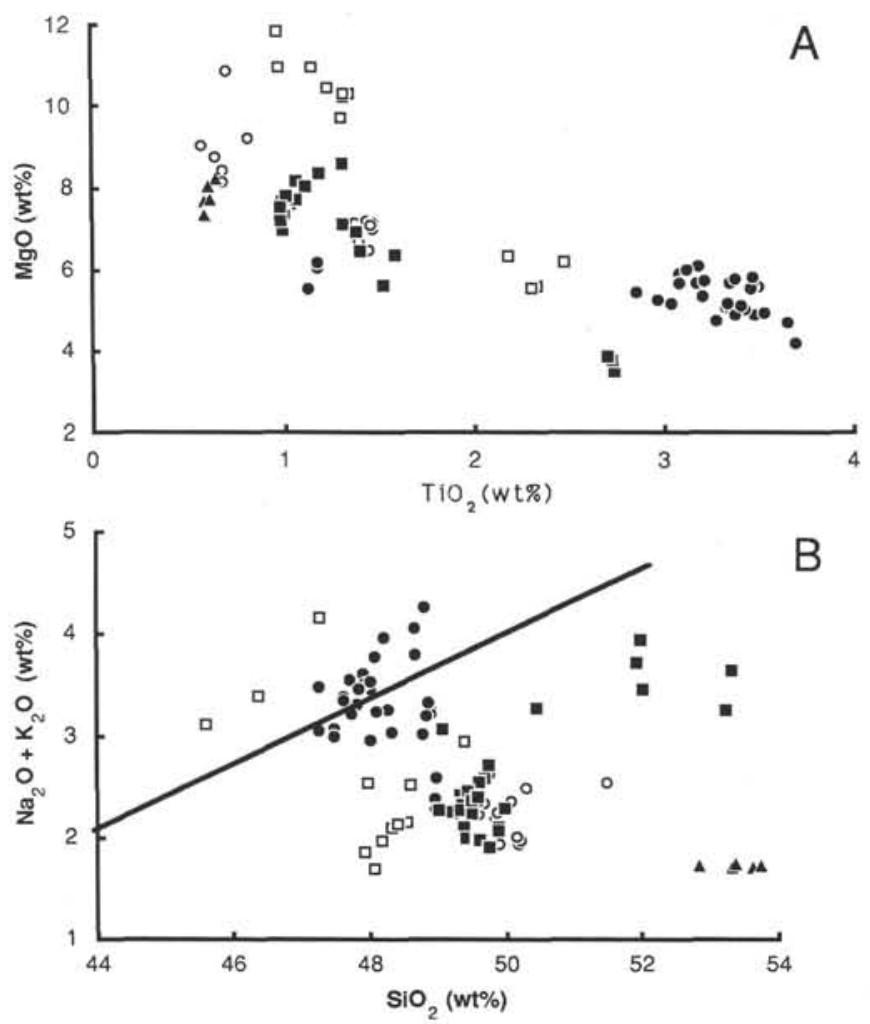

Figure 3. Variation diagrams of the major element chemistry of the bulk rocks and glass from Leg 115. A. $\mathrm{MgO}-\mathrm{TiO}_{2}$ for each drill site and for glass from DSDP Site 236 (Melson et al., 1977). Site 706, solid circles; Site 707, open circles; Site 713, solid squares; Site 715, open squares; DSDP Site 236, triangles. Bulk rocks from all Leg 115 sites except Site 713 have two distinct chemistries. The volcanic turbidite between chemical units 2 and 3 in Site 713 (solid squares) is distinct from the bulk-rock chemistry of Site 713. Glass analyses from other sites are not substantially different from the associated bulk rocks; therefore, these glasses have not been plotted. B. Total alkalis- $\mathrm{SiO}_{2}$ for the bulk rocks from each site and for the glasses from Site 713 and DSDP Site 236. Alkali and tholeiite fields as in Figure 2. Symbols are the same as for Figure 3A.
715 has a single analysis that does not appear to be part of the unit; a second analysis, however, from lower in the same flow, is similar to the other five analyses of the unit, which is consistent with classifying these flows as a single chemical unit.

Thin sections from each of the chemical units at each site were selected for further analysis by electron microprobe. The microprobe analyses of glasses, olivine, feldspar, and pyroxene were performed on the University of Oregon ARL/EDX microprobe using $15-\mathrm{kV}$ accelerating voltage and $0.15-\mu \mathrm{A}$ sample current. The standards for major elements were well-characterized minerals and glass that were close in composition to the unknowns (e.g., Kakanui augite, anorthite, Lake County labradorite, Springwater olivine, and glasses made from basalt and diopside with $15 \%$ jadeite component). The minor elements $\mathrm{Na}, \mathrm{Ti}$, $\mathrm{Cr}, \mathrm{Mn}, \mathrm{K}$, and $\mathrm{Ni}$ were standardized on mineral and glass standards that had high concentrations of these elements relative to the unknowns to obtain higher precision. Peaks and backgrounds were counted for $20 \mathrm{~s}$ and on-line data reduction followed standard procedures of Bence and Albee (1968) and Albee and Ray (1970). Statistical precision is $\pm 2 \%$ or better for major elements and usually $\pm 5 \%$ or better for minor elements.

Titanomagnetite analyses were performed on the University of Washington JEOL 733 microprobe using an accelerating voltage of $15-\mathrm{KV}$ and a beam current of $25 \mathrm{nA}$. Standards for these analyses were chromite 52NL11, Elba hematite, Sawyer ilmenite, diopside jadeite, nickel olivine, and manganese silicate. Counting times were a maximum of $40 \mathrm{~s}$, but counting ceased when precision based on total counts was better than $1 \%$. The on-line correction procedure was the same as that for the ARL microprobe.

\section{SAMPLE DESCRIPTIONS AND RESULTS}

The following descriptions are bâsed on the shipboard core and thin section descriptions and on the shipboard chemical analyses (Backman, Duncan, et al., 1988). Mineral amounts are estimates of modal abundance from the thin sections. Chemical units were defined on downhole XRF major and trace elements as described above and the microprobe mineral analyses are grouped by the chemical units shown in Figure 4.

\section{Site 706 (Analogous to Iceland)}

Basement rocks were recovered from all three holes of Site 706 , which was located on the eastern margin of the Saya de Malha-Nazareth banks (Fig. 1). In Hole 706A, a single piece of basalt was found in the core catcher at the base of the hole, and in Hole 706B six basalt pieces were recovered from the $0.5 \mathrm{~m}$ of basement that was drilled. About $20 \mathrm{~m}$ of basalt was recovered from $77 \mathrm{~m}$ of basement at Hole $706 \mathrm{C}$. The many glass contacts between 30 thin lithologic units (flows) suggests that the basalts were erupted underwater. Additional evidence for submarine eruption comes from the absence of oxidized contacts between flows; the high vesicularity (commonly as high as $35 \%$ ), however, implies that this was a shallow-water environment.

\section{Chemistry}

These basalts form two distinct compositional groups (Figs. 3 and 4). One group includes the basalts from Holes 706A, $706 \mathrm{~B}$, and the upper 30 flows of $706 \mathrm{C}$; they are high in $\mathrm{TiO}_{2}$ $(2.8-3.8 \mathrm{wt} \%)$ and are similar in chemistry to an unusual group of evolved lavas known as the giant plagioclase basalts in the lower part of the Deccan Traps (Beane et al., 1986). This hightitanium group from Site 706 is also similar to the lavas of Réunion Island (Fisk et al., 1988). Within the upper 30 flows of Site $706 \mathrm{C}$, there is a subtle change in major element chemistry and a pronounced difference in $\mathrm{Cr}$ (Fig. 4) between flows 21 and 

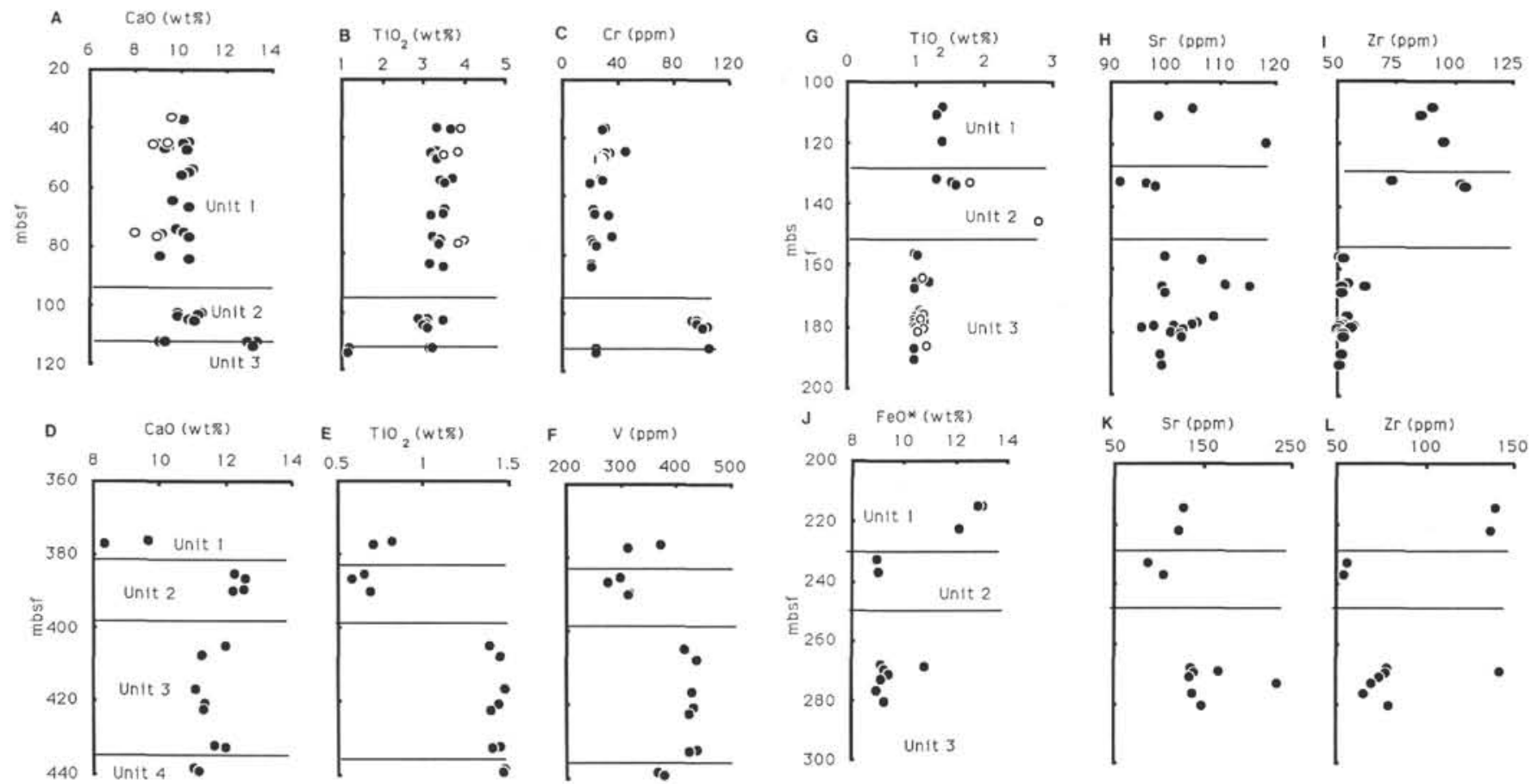

Figure 4. Downhole chemical variation for selected elements determined by X-ray fluorescence. A-C. Site 706. D-F. Site 707. G-I. Site 713. J-L. Site 715. Chemical units were defined by abrupt changes in chemistry. Glass analyses from Sites 706 and 713 are shown as open circles. The high-TiO 2 glass included with unit 2 of Site 713 is from a volcanic turbidite in sediment between units 2 and 3 and is clearly not part of unit 2 .

26. We have separated these flows into chemical units 1 and 2 . Chemical unit 3 from Site $706 \mathrm{C}$ was found in the lowest flows (31 and 32) and has low $\mathrm{TiO}_{2}(1.1 \mathrm{wt} \%)$ and low total alkalis, but similar $\mathrm{MgO}$ content to the upper unit. Units 1 and 2, with a $\mathrm{TiO}_{2}$ abundance that is three times that of unit 3 , cannot be derived from the same parent magma as unit 3 by fractional crystallization. They could be derived, however, from distinct mantle sources based on different $\mathrm{Nb} / \mathrm{Y}$ values (Fisk et al., 1989).

\section{Mineralogy}

The primary minerals of the two main chemical units at Site 706 are also distinctive. The upper high-titanium units have a uniform phenocryst mineralogy that is typical of evolved basalts; plagioclase and augite are always present, and olivine or pseudomorphs of olivine are sometimes present. The lower chemical unit is characterized by large (up to $30 \mathrm{~mm}$ ) plagioclase phenocrysts (Backman, Duncan, et al., 1988, fig. 30).

In detail, chemical unit 1 has small $(<2 \mathrm{~mm})$ plagioclase phenocrysts that make up $10 \%-30 \%$ of the rock. Augite phenocrysts are never more abundant than plagioclase and make up $2 \%-25 \%$ of the rock. They are always less than $1 \mathrm{~mm}$ at their greatest dimension. Olivine phenocrysts, although mostly altered, composed up to $5 \%$ of some lavas but were entirely absent from others. They were originally present in 4 of 50 thin sections examined, but were preserved only in flows 17 and 19 (between 75 and $77 \mathrm{mbsf}$ ).

No magnetite phenocrysts were observed, even in the basalts with $15 \mathrm{wt} \% \mathrm{FeO}$ and $3.3 \mathrm{wt} \% \mathrm{TiO}_{2}$, which is also typical of iron-titanium-rich, ocean-floor basalts such as those of the Galapagos Rift (Fisk et al., 1982; Perfit and Fornari, 1983). Chromites were not reported in the thin sections, but one chromerich magnetite was analyzed in unit 2 . A small amount of $\mathrm{Cr}$ rich magnetite could account for the higher $\mathrm{Cr}$ content in this unit (Fig. 4). The groundmass was either fine-grained plagioclase, augite, and oxides or a combination of these minerals with glass. Some of the quenched margins of pillows and flows contain substantial glass that has been devitrified and altered to clay.

Mineralogically, chemical unit 3 (flows 31 and 32) is not significantly different from the upper unit, except for the presence of large plagioclase phenocrysts that constitute 15 modal $\%$ of these flows. Augite (1\%-10\%) and olivine (1\% or less) are also present in this lower chemical unit. The groundmass is plagioclase, augite, glass, and opaque oxides. No glass was preserved in this unit.

\section{Alteration}

In the thin sections examined from Site 706, alteration ranged from $3 \%$ to $85 \%$ (by volume). Olivine was usually altered to clay (Fisk and Howard, this volume), but plagioclase and augite phenocrysts and groundmass are untouched by alteration. The major alteration is concentrated in the quenched glass at the flow margins and in interstitial glass. In spite of this pervasive alteration, glass was preserved near the sediment-basalt interface as well as in three sections of the core from Hole 706C (at 37, 45-46, and 75-77 mbsf). Below $77 \mathrm{mbsf}$, all glass and olivine were altered to clay. Unit 3 has between $19 \%$ and $65 \%$ clay replacing olivine and glass.

\section{Mineral Chemistry}

We studied 12 thin sections in detail at this site. Plagioclase and augite were analyzed by microprobe in each chemical unit of Site 706, and glass and olivine were analyzed where they were preserved. Oxide minerals were not found as phenocrysts, but some groundmass titanomagnetites were probed in a few thin sections. In addition, glass, plagioclase, and pyroxene grains were analyzed in the sulfide-cemented sandstone found above unit 1 at Hole 706B. These analyses are included in histograms of the mineral compositions.

Representative microprobe analyses of minerals and glasses for Site 706 are given in Tables 1 through 5, and histograms of 
Table 1. Microprobe analyses of plagioclase phenocrysts, Site $\mathbf{7 0 6 .}$

\begin{tabular}{|c|c|c|c|c|c|c|c|c|c|c|c|c|}
\hline $\begin{array}{l}\text { Hole no. } \\
\text { Unit no. } \\
\text { Core, section } \\
\text { Interval (cm) } \\
\text { Depth (mbsf) } \\
\text { Analysis no. }\end{array}$ & $\begin{array}{l}706 \mathrm{~A} \\
1 \\
6 \mathrm{H}-4 \\
20-24 \\
41.30 \\
1\end{array}$ & 2 & 3 & $\begin{array}{l}706 \mathrm{~B} \\
1 \\
7 \mathrm{X}-\mathrm{CC} \\
17-20 \\
36.92 \\
1\end{array}$ & 2 & 3 & $\begin{array}{l}706 \mathrm{~B} \\
1 \\
7 \mathrm{X}-\mathrm{CC} \\
20-27 \\
36.90 \\
1\end{array}$ & 2 & 3 & $\begin{array}{l}706 \mathrm{C} \\
1 \\
2 \mathrm{R}-1 \\
76-80 \\
45.16 \\
1\end{array}$ & 2 & 3 \\
\hline $\mathrm{SiO}_{2}$ & 52.22 & 50.25 & 54.10 & 61.13 & 58.45 & 57.14 & 53.20 & 51.69 & 50.98 & 52.37 & 50.65 & 50.38 \\
\hline $\mathrm{Al}_{2} \mathrm{O}_{3}$ & 28.19 & 29.59 & 25.64 & 24.31 & 26.09 & 26.29 & 28.60 & 28.99 & 29.45 & 27.93 & 29.31 & 29.46 \\
\hline $\mathrm{FeO}$ & 0.95 & 0.92 & 1.33 & 0.57 & 0.51 & 0.74 & 0.72 & 0.37 & 0.90 & 1.09 & 0.89 & 0.32 \\
\hline $\mathrm{CaO}$ & 12.75 & 13.44 & 10.15 & 6.49 & 8.02 & 8.84 & 11.90 & 12.65 & 12.97 & 11.39 & 12.88 & 12.72 \\
\hline $\mathrm{Na}_{2} \mathrm{O}$ & 4.66 & 4.50 & 5.93 & 7.36 & 6.64 & 6.44 & 4.89 & 4.29 & 4.25 & 4.94 & 4.73 & 4.24 \\
\hline $\mathrm{K}_{2} \mathrm{O}$ & 0.33 & 0.25 & 0.45 & 0.50 & 0.42 & 0.39 & 0.37 & 0.32 & 0.31 & 0.39 & 0.23 & 0.25 \\
\hline Total & 99.11 & 98.96 & 97.61 & 100.37 & 100.13 & 99.84 & 99.69 & 98.81 & 98.85 & 98.12 & 99.25 & 97.87 \\
\hline An & 59.2 & 61.4 & 47.4 & 31.9 & 39.1 & 42.2 & 56.2 & 64.4 & 65.1 & 54.7 & 59.2 & 61.5 \\
\hline Notes & c & $r$ & $\mathrm{~m}$ & $\mathrm{~m}$ & c & $\mathrm{r}$ & $\mathrm{m}$ & c & $\mathrm{r}$ & $\mathrm{m}$ & r & c \\
\hline
\end{tabular}

\begin{tabular}{|c|c|c|c|c|c|c|c|c|c|c|c|c|c|}
\hline Analysis & 1 & 2 & 3 & 1 & 2 & 1 & 2 & 3 & 1 & 2 & 3 & 1 & 2 \\
\hline $\mathrm{SiO}_{2}$ & 49.18 & 50.84 & 52.31 & 53.48 & 52.59 & 52.86 & 51.82 & 55.70 & 50.30 & 54.18 & 53.34 & 51.44 & 53.88 \\
\hline $\mathrm{CaO}$ & 15.15 & 12.39 & 11.85 & 11.88 & 12.01 & 11.69 & 12.19 & 9.29 & 14.44 & 11.71 & 11.41 & 15.09 & 11.71 \\
\hline $\mathrm{Na}_{2} \mathrm{O}$ & 2.87 & 4.08 & 4.33 & 4.00 & 4.64 & 4.67 & 3.98 & 6.04 & 2.97 & 4.55 & 4.62 & 2.74 & 5.12 \\
\hline $\mathrm{K}_{2} \mathrm{O}$ & 0.15 & 0.22 & 0.25 & 0.26 & 0.23 & 0.30 & 0.22 & 0.35 & 0.14 & 0.23 & 0.17 & 0.10 & 0.19 \\
\hline Total & 99.96 & 97.94 & 98.90 & 98.71 & 99.47 & 98.05 & 97.58 & 97.76 & 98.37 & 98.80 & 98.56 & 100.03 & 98.82 \\
\hline
\end{tabular}

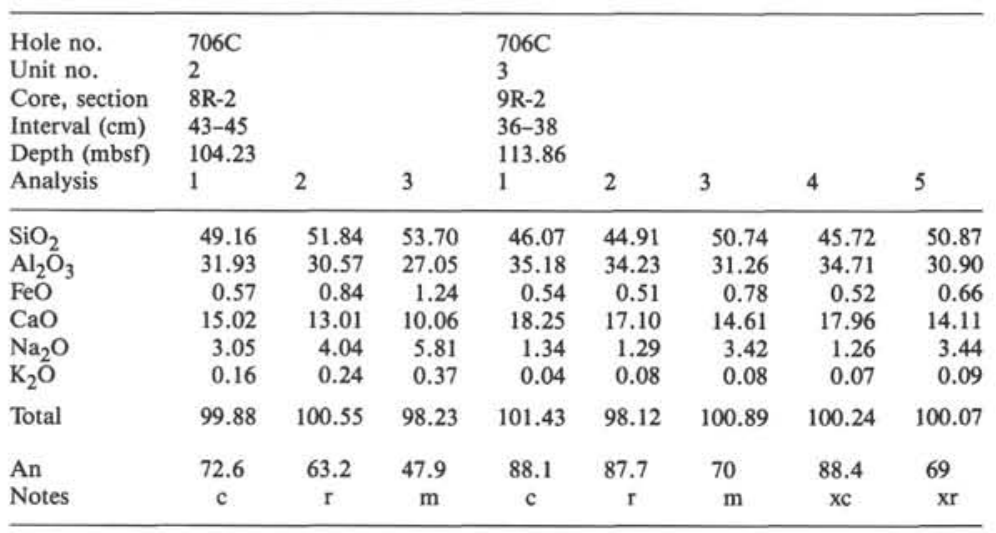

Notes: $\mathrm{c}=$ core, $\mathrm{r}=\mathrm{rim}, \mathrm{m}=$ microphenocryst, $\mathrm{xc}=$ xenocryst core, and $\mathrm{xr}=$ xenocryst rim.

all of the plagioclase and augite compositions are presented in Figures 5 and 6 . The precision of the anorthite composition is $\pm 2 \%$ or better on the basis of counting statistics made on calcium and sodium. One sample at the top of Hole 706B (Table 1) has low anorthite $\mathrm{An}_{32-42}$; however, this feldspar is not from a flow but from a sandstone cemented with sulfide at the interface between the basalts and sediment.

The anorthite content of plagioclase in the thick upper unit has a mode of $\mathrm{An}_{61}$ (Table 1 and Fig. 5). There appears to be no systematic change in mineral chemistry with depth since all thin sections have phenocryst cores of $\mathrm{An}_{60-61}$, except for those from the sandstone (115-706B-7X-CC, 17-20 cm), for which all of the feldspars are less than $\mathrm{An}_{43}$. The equilibrium plagioclase composition is fixed at a specific anorthite content for a given magma composition and temperature, so the wide range of com- positions observed in this upper unit indicates that several processes may have been active during the crystallization of these magmas. These include mixing of magmas and crystallization under a range of pressures and temperatures and water contents.

Even though there are minor differences in the bulk rock chemistry of units 1 and 2 the mineralogy of the two units are identical except for the presence of $\mathrm{Cr}$-rich magnetite in unit 2 (Table 5). Unit 3, however, is significantly different from the upper units and contains plagioclase phenocryst cores that range from $\mathrm{An}_{83-88}$. This high anorthite content can reflect a higher temperature and $\mathrm{CaO} / \mathrm{Na}_{2} \mathrm{O}$ of this magma compared to the upper units, or it may result from the incorporation of plagioclase xenocrysts in unit 3.

Augite phenocrysts (Table 2 and Fig. 6) have a wide range of compositions within the upper chemical unit (flows 1-17). Au- 
Table 2. Microprobe analyses of clinopyroxenes, Site $\mathbf{7 0 6}$.

\begin{tabular}{|c|c|c|c|c|c|c|c|c|}
\hline $\begin{array}{l}\text { Hole no. } \\
\text { Unit no. } \\
\text { Core, section } \\
\text { Interval (cm) } \\
\text { Depth (mbsf) } \\
\text { Analysis no. }\end{array}$ & $\begin{array}{l}706 \mathrm{~A} \\
1 \\
6 \mathrm{H}-4 \\
20-24 \\
41.30 \\
1\end{array}$ & 2 & $\begin{array}{l}706 \mathrm{~A} \\
1 \\
7 \mathrm{X}-\mathrm{CC} \\
17-20 \\
36.92 \\
1\end{array}$ & 2 & $\begin{array}{l}706 \mathrm{~B} \\
1 \\
7 \mathrm{X}-\mathrm{CC} \\
20-27 \\
36.90 \\
1\end{array}$ & 2 & 3 & 4 \\
\hline $\mathrm{SiO}_{2}$ & 48.00 & 46.72 & 52.02 & 49.16 & 48.34 & 47.67 & $\begin{array}{r}47.97 \\
1.67\end{array}$ & 50.88 \\
\hline $\mathrm{TiO}_{2}$ & 1.89 & 2.29 & 0.70 & 0.80 & 1.79 & 1.34 & 1.67 & 0.92 \\
\hline $\mathrm{Al}_{2} \mathrm{O}_{3}$ & 5.23 & 5.19 & 1.26 & 1.08 & 5.19 & 4.78 & 4.41 & 2.56 \\
\hline $\mathrm{FeO}$ & 11.21 & 12.60 & 13.42 & 13.37 & 9.76 & 9.71 & 10.64 & 9.48 \\
\hline $\mathrm{MnO}$ & 0.24 & 0.30 & 0.47 & 0.45 & 0.21 & 0.18 & 0.22 & 0.25 \\
\hline $\mathrm{MgO}$ & 14.25 & 12.75 & 12.18 & 12.69 & 13.84 & 14.09 & 13.69 & 15.61 \\
\hline $\mathrm{CaO}$ & 19.36 & 19.17 & 19.98 & 20.08 & 19.86 & 20.09 & 19.91 & 18.89 \\
\hline $\mathrm{Na}_{2} \mathrm{O}$ & 0.32 & 0.35 & 0.29 & 0.32 & 0.40 & 0.47 & 0.41 & 0.35 \\
\hline $\mathrm{Cr}_{2} \mathrm{O}_{3}$ & 0.17 & 0.05 & ${ }^{\mathrm{a}} 0.04$ & ${ }^{\mathrm{a}} 0.04$ & 0.15 & 0.11 & 0.06 & 0.13 \\
\hline Tota & 100.66 & 99.42 & 100.34 & 98.00 & 99.55 & 98.44 & 98.97 & 99.06 \\
\hline Notes & c & r & c & r & c & $r$ & c & $r$ \\
\hline Mg\# & 78 & 72 & 62 & 64 & 77 & 83 & 88 & 88 \\
\hline
\end{tabular}

\begin{tabular}{|c|c|c|c|c|c|c|c|c|c|c|c|c|}
\hline Hole no. & $706 \mathrm{C}$ & & $706 \mathrm{C}$ & & $706 \mathrm{C}$ & & $706 \mathrm{C}$ & & & $706 \mathrm{C}$ & & \\
\hline Unit no. & 1 & & 1 & & 1 & & 1 & & & 1 & & \\
\hline Core, section & 2R-1 & & $2 \mathrm{R}-2$ & & $2 \mathrm{R}-2$ & & $5 R-1$ & & & $6 \mathrm{R}-1$ & & \\
\hline Interval (cm) & $76-80$ & & $2-4$ & & $115-118$ & & $83-85$ & & & $46-50$ & & \\
\hline Depth (mbsf) & 45.16 & & 46.00 & & 47.13 & & 74.03 & & & 83.36 & & \\
\hline Analysis & 1 & 2 & 1 & 2 & 1 & 2 & 1 & 3 & 4 & 1 & 2 & \\
\hline $\mathrm{SiO}_{2}$ & 50.33 & 47.93 & 49.26 & 47.21 & 49.21 & 51.47 & 51.48 & 49.67 & 49.10 & 48.07 & 50.75 & 50.18 \\
\hline $\mathrm{TiO}_{2}$ & 0.77 & 1.60 & 0.99 & 1.60 & 0.93 & 0.96 & 0.92 & 1.03 & 1.79 & 2.08 & 0.94 & 1.33 \\
\hline $\mathrm{Al}_{2} \mathrm{O}_{3}$ & 1.95 & 4.05 & 3.86 & 4.82 & 3.00 & 3.47 & 3.45 & 3.32 & 4.25 & 4.40 & 2.83 & 4.01 \\
\hline $\mathrm{FeO}$ & 10.12 & 10.38 & 9.97 & 9.89 & 9.39 & 9.74 & 11.44 & 14.16 & 11.35 & 11.67 & 10.71 & 9.79 \\
\hline $\mathrm{MnO}$ & 0.29 & 0.16 & 0.24 & 0.24 & 0.24 & 0.26 & 0.33 & 0.33 & 0.27 & 0.28 & 0.28 & 0.26 \\
\hline $\mathrm{MgO}$ & 17.60 & 13.94 & 14.52 & 12.91 & 15.16 & 13.88 & 13.34 & 9.86 & 13.29 & 12.62 & 14.71 & 12.91 \\
\hline $\mathrm{CaO}$ & 16.80 & 20.27 & 19.26 & 20.36 & 20.36 & 20.57 & 19.48 & 19.68 & 18.56 & 19.64 & 18.44 & 20.56 \\
\hline $\mathrm{Na}_{2} \mathrm{O}$ & 0.30 & 0.41 & 0.41 & 0.41 & 0.33 & 0.27 & 0.33 & 0.27 & 0.38 & 0.24 & 0.29 & 0.35 \\
\hline $\mathrm{Cr}_{2} \mathrm{O}_{3}$ & 0.11 & 0.05 & 0.14 & 0.12 & 0.10 & 0.10 & ${ }^{\mathrm{a}} 0.04$ & ${ }^{\mathrm{a}} 0.04$ & 0.09 & 0.05 & 0.09 & 0.09 \\
\hline Total & 98.31 & 98.80 & 98.65 & 97.58 & 100.74 & 100.74 & 100.80 & 98.41 & 99.08 & 99.05 & 99.04 & 99.49 \\
\hline Notes & c & $r$ & $r$ & c & c & $r$ & c & $r$ & c & $r$ & c & c \\
\hline $\mathrm{Mg \#}$ & 76 & 70 & 88 & 88 & 74 & 72 & 68 & 55 & 69 & 69 & 72 & 70 \\
\hline
\end{tabular}

\begin{tabular}{|c|c|c|c|c|c|}
\hline $\begin{array}{l}\text { Hole no. } \\
\text { Unit no. } \\
\text { Core, section } \\
\text { Interval (cm) } \\
\text { Depth (mbsf) } \\
\text { Analysis no. }\end{array}$ & $\begin{array}{l}706 \mathrm{C} \\
2 \\
8 \mathrm{R}-2 \\
43-45 \\
104.23 \\
1\end{array}$ & 2 & $\begin{array}{l}706 \mathrm{C} \\
3 \\
9 \mathrm{R}-2 \\
36-38 \\
113.86 \\
1\end{array}$ & 2 & 3 \\
\hline $\begin{array}{l}\mathrm{SiO}_{2} \\
\mathrm{TiO}_{2} \\
\mathrm{Al}_{2} \mathrm{O}_{3} \\
\mathrm{FeO} \\
\mathrm{MnO} \\
\mathrm{MgO} \\
\mathrm{CaO} \\
\mathrm{Na}_{2} \mathrm{O} \\
\mathrm{Cr}_{2} \mathrm{O}_{3}\end{array}$ & $\begin{array}{r}50.63 \\
1.08 \\
2.46 \\
9.02 \\
0.25 \\
14.89 \\
19.20 \\
0.37 \\
0.28\end{array}$ & $\begin{array}{r}48.60 \\
1.92 \\
10.30 \\
10.21 \\
0.37 \\
11.27 \\
14.47 \\
0.43 \\
0.05\end{array}$ & $\begin{array}{r}50.49 \\
0.65 \\
3.64 \\
7.03 \\
0.15 \\
16.10 \\
21.88 \\
0.28 \\
0.05\end{array}$ & $\begin{array}{r}50.74 \\
0.63 \\
4.12 \\
7.44 \\
0.21 \\
15.50 \\
20.68 \\
0.30 \\
0.05\end{array}$ & $\begin{array}{r}51.74 \\
0.53 \\
2.65 \\
6.71 \\
0.20 \\
15.85 \\
21.29 \\
0.24 \\
0.05\end{array}$ \\
\hline $\begin{array}{l}\text { Total } \\
\text { Notes }\end{array}$ & $\begin{array}{c}98.18 \\
\mathrm{c}\end{array}$ & $\begin{array}{c}97.50 \\
\mathrm{r}\end{array}$ & $\begin{array}{c}100.27 \\
\mathrm{~m}\end{array}$ & $\begin{array}{c}99.67 \\
c\end{array}$ & $\begin{array}{c}99.25 \\
\mathrm{r}\end{array}$ \\
\hline $\mathrm{Mg \#}$ & 76 & 66 & 91 & 83 & 84 \\
\hline
\end{tabular}

Notes: $\mathrm{c}=$ core, $\mathrm{r}=\mathrm{rim}$, and $\mathrm{m}=$ microphenocryst.

${ }^{\mathrm{a}} \mathrm{Minimum}$ detection limit for $\mathrm{Cr}_{2} \mathrm{O}_{3}$ is $0.04 \mathrm{wt} \%$.

gite in flow 1 has an $\mathrm{Mg} \#\left(100 \mathrm{Mg}^{2+} /\left[\mathrm{Mg}^{2+}+\mathrm{Fe}^{2+}\right]\right)$ range of 77-88; in flow 14 the $\mathrm{Mg} \#$ range is 55-76; and in flow 17 the range is 73-79. These distinct augite compositions from separate flows suggest that although the flows have the same chemical composition they are not a single eruption of pillow basalts with many internal chilled margins, but they are, in fact, separate flows.
At Site 706 glass was preserved only in four flows of unit 1 and in the sulfide-cemented sandstone at the sediment/basalt interface in Hole 706B (Table 3). The glasses from the four flows in unit 1 are similar to their corresponding bulk-rock compositions with the exception that the glasses have lower $\mathrm{MgO}$ abundance (4.3-4.8 wt \%) than the average of the bulk rock analyses for unit 1 (5.3 wt \%; Fisk et al., 1989). 
Table 3. Microprobe analyses of glasses, Site 706.

\begin{tabular}{|c|c|c|c|c|c|c|c|c|c|c|c|}
\hline $\begin{array}{l}\text { Hole no. } \\
\text { Unit no. } \\
\text { Core, section } \\
\text { Interval }(\mathrm{cm}) \\
\text { Depth (mbsf) } \\
\text { Average }(N)\end{array}$ & $\begin{array}{l}706 \mathrm{~B} \\
1 \\
7 \mathrm{X}-\mathrm{CC} \\
\mathrm{a}_{17-20} \\
36.87 \\
1\end{array}$ & 1 & 1 & 1 & 1 & 1 & $\begin{array}{l}706 \mathrm{~B} \\
1 \\
7 \mathrm{X}-\mathrm{CC} \\
\mathrm{a}_{20-27} \\
36.90 \\
8\end{array}$ & $\begin{array}{l}706 \mathrm{C} \\
1 \\
2 \mathrm{R}-1 \\
76-80 \\
45.06 \\
8\end{array}$ & $\begin{array}{l}706 C \\
1 \\
2 R-2 \\
2-4 \\
46.00 \\
5\end{array}$ & $\begin{array}{l}706 C \\
1 \\
5 R-2 \\
102-105 \\
75.72 \\
5\end{array}$ & $\begin{array}{l}706 \mathrm{C} \\
1 \\
5 \mathrm{R}-3 \\
44-48 \\
76.64 \\
5\end{array}$ \\
\hline $\begin{array}{l}\mathrm{SiO}_{2} \\
\mathrm{TiO}_{2} \\
\mathrm{Al}_{2} \mathrm{O}_{3} \\
\mathrm{FeO} \\
\mathrm{MnO} \\
\mathrm{MgO} \\
\mathrm{CaO} \\
\mathrm{Na}_{2} \mathrm{O} \\
\mathrm{K}_{2} \mathrm{O}\end{array}$ & $\begin{array}{r}48.73 \\
3.26 \\
13.89 \\
14.36 \\
0.25 \\
4.65 \\
9.35 \\
3.42 \\
0.97\end{array}$ & $\begin{array}{r}49.29 \\
2.54 \\
13.11 \\
12.95 \\
0.24 \\
6.56 \\
10.66 \\
3.18 \\
0.77\end{array}$ & $\begin{array}{r}50.34 \\
3.63 \\
14.64 \\
12.78 \\
0.24 \\
4.00 \\
8.12 \\
3.44 \\
1.33\end{array}$ & $\begin{array}{r}50.64 \\
2.84 \\
14.26 \\
12.90 \\
0.26 \\
3.53 \\
7.50 \\
3.77 \\
1.25\end{array}$ & $\begin{array}{r}47.65 \\
3.38 \\
14.08 \\
14.11 \\
0.25 \\
4.74 \\
9.28 \\
3.23 \\
0.94\end{array}$ & $\begin{array}{r}54.70 \\
2.36 \\
14.76 \\
11.60 \\
0.25 \\
2.32 \\
6.85 \\
3.50 \\
2.28\end{array}$ & $\begin{array}{r}47.95 \\
3.94 \\
12.71 \\
15.62 \\
0.26 \\
4.70 \\
9.64 \\
2.95 \\
0.84\end{array}$ & $\begin{array}{r}48.15 \\
3.87 \\
12.93 \\
15.34 \\
0.25 \\
4.76 \\
9.41 \\
3.04 \\
0.79\end{array}$ & $\begin{array}{r}45.24 \\
3.53 \\
12.18 \\
13.28 \\
0.23 \\
4.45 \\
8.84 \\
3.01 \\
0.73\end{array}$ & $\begin{array}{r}48.84 \\
4.02 \\
12.26 \\
15.53 \\
0.29 \\
4.33 \\
7.99 \\
2.40 \\
0.88\end{array}$ & $\begin{array}{r}48.75 \\
3.86 \\
12.49 \\
15.30 \\
0.28 \\
4.38 \\
8.93 \\
2.49 \\
0.90\end{array}$ \\
\hline Total & 98.92 & 99.34 & 98.57 & 97.00 & 97.70 & 98.65 & 98.65 & 98.58 & 91.53 & 96.58 & 97.42 \\
\hline
\end{tabular}

${ }^{\text {a }}$ Glass in sulfide nodule between sediments and Unit 1.

Table 4. Microprobe analyses of olivine microphenocrysts, Site 706.

\begin{tabular}{|c|c|c|c|c|c|c|c|}
\hline $\begin{array}{l}\text { Hole no. } \\
\text { Unit no. } \\
\text { Core, section } \\
\text { Interval (cm) } \\
\text { Depth (mbsf) } \\
\text { Analysis }\end{array}$ & $\begin{array}{l}706 \mathrm{C} \\
1 \\
5 \mathrm{R}-2 \\
102-105 \\
75.72 \\
1\end{array}$ & 2 & 3 & 4 & $\begin{array}{l}706 \mathrm{C} \\
1 \\
5 \mathrm{R}-3 \\
44-48 \\
76.64 \\
1\end{array}$ & 2 & 3 \\
\hline $\mathrm{SiO}_{2}$ & 37.20 & 37.38 & 37.85 & 36.06 & 36.90 & 36.75 & 36.54 \\
\hline $\mathrm{FeO}^{2}$ & 28.52 & 28.97 & 28.29 & 28.38 & 28.65 & 27.78 & 28.35 \\
\hline $\mathrm{MnO}$ & 0.43 & 0.50 & 0.48 & 0.47 & 0.46 & 0.40 & 0.45 \\
\hline $\mathrm{MgO}$ & 32.07 & 31.69 & 31.94 & 32.65 & 32.47 & 32.59 & 32.05 \\
\hline $\mathrm{NiO}$ & 0.11 & 0.11 & 0.11 & 0.12 & 0.17 & 0.11 & 0.11 \\
\hline Total & 98.32 & 98.64 & 98.66 & 97.68 & 98.65 & 97.64 & 97.51 \\
\hline Fo & 66.3 & 65.7 & 66.4 & 66.8 & 66.4 & 67.3 & 66.4 \\
\hline
\end{tabular}

Olivine is preserved in two flows (17 and 19; Table 4), and these are two of the units in which glass was also preserved. This olivine has a restricted range $\left(\mathrm{Fo}_{66-67}\right)$, and the glasses from flows 17 and 19 have $\mathrm{MgO} / \mathrm{FeO}$ ratios of $0.328-0.335$. These glasses would be in equilibrium with an olivine of $\mathrm{Fo}_{66}$, assuming that the $\mathrm{Mg}-\mathrm{Fe}$ exchange coefficient for olivine and glass $\left(K_{D}\right)$ is 0.306 (Roeder and Emslie, 1970) and $85 \mathrm{wt} \%$ of the total iron in the magma was $\mathrm{FeO}$. The geothermometer of Ford et al. (1983) indicates that this olivine crystallized at $1135^{\circ} \mathrm{C}$. The bulk-rock composition of flow 17 , however, has a $\mathrm{MgO} / \mathrm{FeO}$ ratio of 0.368 , so the rock is enriched in $\mathrm{MgO}$ relative to the glass, indicating that the glass was more evolved than the bulk rock or that there was accumulated olivine or augite in the host rock. The thin sections of this flow contain $3 \%-5 \%$ olivine and $10 \%$ augite, which
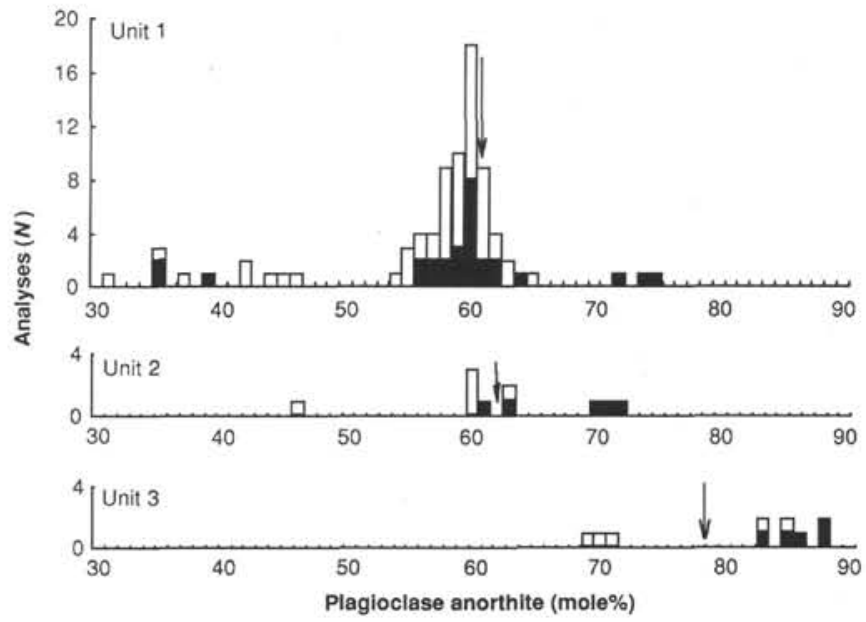

Figure 5. Histogram of anorthite content of plagioclase in each of the three chemical units from Site 706. Units 1 and 2 are chemically and mineralogically similar. The low anorthite plagioclases $\left(<A n_{50}\right)$ are from a sandstone at the top of the unit that is made of silicic ash cemented with iron sulfide. These feldspars are unrelated to those in the units below. Chemical unit 3 contains $\mathrm{An}_{83-88}$ megacrysts that are too anorthitic to have crystallized from the host magma. In this and subsequent histograms, core compositions are designated by solid bars, rim compositions by open bars, and arrows show the equilibrium plagioclase or pyroxene compositions at the liquidus temperature from Table 15.

Table 5. Leg 115 Opaque minerals, Sites 706, 707, 713, and 715.

\begin{tabular}{|c|c|c|c|c|c|c|c|c|c|c|c|c|}
\hline Hole no. & $706 \mathrm{C}$ & $706 \mathrm{C}$ & $706 \mathrm{C}$ & $707 \mathrm{C}$ & $707 \mathrm{C}$ & $707 \mathrm{C}$ & $707 \mathrm{C}$ & $713 \mathrm{~A}$ & $715 \mathrm{~A}$ & $715 \mathrm{~A}$ & $715 \mathrm{~A}$ & $715 \mathrm{~A}$ \\
\hline Unit no. & 1 & 2 & 2 & 1 & 2 & 3 & 4 & 1 & 1 & 1 & 2 & \\
\hline Core, section & $5 \mathrm{R}-2$ & $8 R-2$ & $8 R-2$ & $22 \mathrm{R}-1$ & 23R-1 & 26R-2 & $28 R-3$ & $15 R-4$ & $23 R-3$ & $23 \mathrm{R}-3$ & $25 \mathrm{R}-3$ & 30R-3 \\
\hline Interval (cm) & $102-105$ & $43-45$ & $43-45$ & $94-95$ & $24-25$ & $126-128$ & $48-50$ & $44-46$ & 44-46 & $44-46$ & $25-27$ & $40-41$ \\
\hline Analysis no. & 1 & 1 & 2 & 1 & 1 & 1 & 1 & 1 & 1 & 2 & 1 & 1 \\
\hline $\mathrm{SiO}_{2}$ & 0.09 & 0 & 0.19 & 0.39 & 0.64 & 0.54 & 0.26 & 0.16 & 0.15 & 0.08 & 0.12 & 0 \\
\hline $\mathrm{TiO}_{2}$ & 17.43 & 5.65 & 17.22 & 14.50 & 17.95 & 21.76 & 17.11 & 19.73 & 25.60 & 52.76 & 27.05 & 47.51 \\
\hline $\mathrm{Al}_{2} \mathrm{O}_{3}$ & 3.82 & 8.03 & 4.00 & 2.79 & 2.51 & 2.10 & 2.41 & 1.36 & 1.88 & 0.12 & 1.22 & 0 \\
\hline $\mathrm{FeO}$ & 69.52 & 48.54 & 68.33 & 77.97 & 74.35 & 71.82 & 75.48 & 74.11 & 64.98 & 41.94 & 68.77 & 49.84 \\
\hline $\mathrm{MnO}$ & 0.37 & 0.35 & 0.40 & 0.27 & 0.33 & 0.44 & 0.37 & 0.56 & 0.64 & 0.42 & 0.52 & 0.51 \\
\hline $\mathrm{MgO}$ & 4.60 & 5.52 & 3.74 & 0.13 & 0.52 & 0.82 & 0.44 & 0.33 & 1.12 & 1.74 & 1.70 & 1.09 \\
\hline $\mathrm{Cr}_{2} \mathrm{O}_{3}$ & 0.36 & 30.65 & 2.33 & 0.04 & 0.02 & 0.03 & 0.03 & 0.02 & 0.08 & 0 & 0 & 0.02 \\
\hline $\mathrm{NiO}$ & 0.07 & 0.05 & 0.05 & 0 & 0.02 & 0.02 & 0.60 & 0 & 0.03 & 0 & 0.09 & 0.03 \\
\hline Total & 96.39 & 98.86 & 96.44 & 96.22 & 96.37 & 97.72 & 96.24 & 96.45 & 94.52 & 97.20 & 99.47 & 99.22 \\
\hline
\end{tabular}




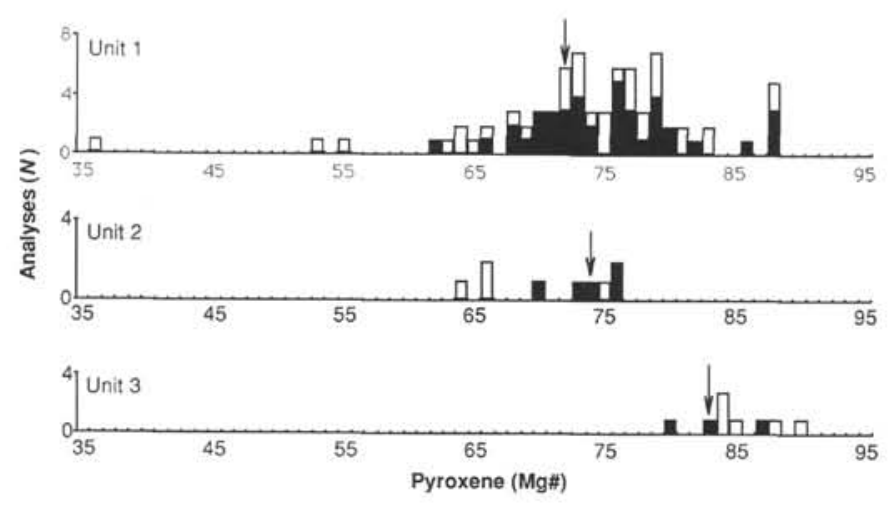

Figure 6. Histogram of the pyroxene $\mathrm{Mg \#}\left(\mathrm{Mg}^{2+} /\left[\mathrm{Mg}^{2+}+\mathrm{Fe}^{2+}\right]\right)$ of magnesium-augites from Site 706. The total iron content from the microprobe analysis has been recalculated to ferric and ferrous iron on the basis of pyroxene stoichiometry and tetrahedral site occupancy, and M1 and M2 site occupancy (Papike et al., 1974) before the Mg\# was calculated. Augites in chemical unit 3 have higher $\mathrm{Mg} \#$ than those in units 1 and 2, reflecting the higher $\mathrm{Mg \#}$ of its host basalt.

is typical of this chemical unit and indicates that there is no significant accumulation of mafic phases in this flow.

Oxide minerals are not abundant at Site 706 , but they were analyzed in flows 17 (chemical unit 1) and 28 (chemical unit 2). All analyses in both units were titanomagnetites (Table 5) except for the core of one grain in Flow 28, which was a spinel with 31 wt $\% \mathrm{Cr}_{2} \mathrm{O}_{3}$.

\section{Site 707 (Early Stages of Rifting)}

These basalts appear to have erupted on the rifted margin of western India and, in contrast with Site 706, the Site 707 basalts erupted as only a few thick flows, possibly with long periods between eruptions given the presence of $1.09 \mathrm{~m}$ of shelly limestone between flows 3 and 4 and $0.36 \mathrm{~m}$ of carbonate sand between flows 4 and 5 . Only five flows were identified in $63 \mathrm{~m}$ of section compared with the 32 flows in $77 \mathrm{~m}$ of section at Site 706.

\section{Chemistry}

The boundary between flows 2 and 3 is a 5 -cm-thick vesicular zone, but the two flows could not be distinguished chemically. Therefore, they have been combined as chemical unit 2 . The other three flows, which were identified by texture, mineralogy, and the presence of interflow sediments, could also be distinguished chemically (Fig. 4). The four chemical units have vesicular upper and lower margins and massive interiors. All the basalts from this site are characterized by their low $\mathrm{K}_{2} \mathrm{O}$ content, and the upper units have extremely low $\mathrm{TiO}_{2}(\leq 0.82 \mathrm{wt} \%$ ), less than all other basalts from the Deccan Traps and from Réunion and Mauritius islands and even less than basalts erupted at the Central Indian spreading ridge.

\section{Mineralogy}

The basalts of Site 707 all contain plagioclase and augite phenocrysts, and minor amounts of relict olivine $(<1$ modal $\%$ ) are found at the base of flow 3 (chemical unit 2), throughout chemical unit 3 , and in chemical unit 4 . Total phenocryst abundance varies from about 4 modal $\%$ in flow 1 to about 50 modal $\%$ in chemical unit 4 . Plagioclase is always more abundant than augite, except in the top flow where there is $1 \%$ plagioclase and $5 \%$ augite. Unit 2 is characterized by abundant $(7 \%-20 \%)$ plagioclase up to $5 \mathrm{~mm}$ across and subordinate augite (2\%-15\%) less than $1 \mathrm{~mm}$ across. Glomerocrysts of plagioclase and augite make up $30 \%$ of one thin section from unit 2 .
Unit 3 is enormously thick $(40 \mathrm{~m})$; the mineralogy is dominated by plagioclase phenocrysts $(7 \%-22 \%)$ and augite is significantly less abundant $(1 \%-7 \%)$. Also found within unit 3 is $1 \%-3 \%$ magnetite. Unit 4 is similar to unit 3 except that the base of unit 4 has only plagioclase. All flows have a fine-grained groundmass of plagioclase, augite, and, in some cases, opaque oxides and black microcrystalline glass or altered glass.

\section{Alteration}

The four chemical units have undergone moderate degrees of alteration ranging from $10 \%$ to $70 \%$ in thin section. Primary minerals have been replaced with clays and carbonates, and vesicles are filled with these minerals. Chemical unit 3 appears to be the least altered, whereas chemical unit 1 is the most altered. Of the primary minerals, olivine is always converted to clay, and in unit 1, many of the augite phenocrysts and much of the groundmass are also converted to clay. In unit 2 the pyroxene and plagioclase phenocrysts have resisted alteration, but some of the groundmass pyroxene is altered to saponite (Fisk and Howard, this volume). In unit 3 plagioclase and augite are preserved, but olivine is converted to clay. In the groundmass about $25 \%$ of the minerals are altered to clay, although some thin sections have little or no alteration of phenocrysts or groundmass. Roughly $50 \%$ of unit 4 is also altered to clay, which replaces plagioclase and clinopyroxene in the groundmass. Details of the clay mineralogy and chemistry are given elsewhere (Fisk and Howard, this volume).

\section{Mineral Chemistry}

Nine thin sections from the four chemical units (5 flows) were analyzed by electron microprobe. Plagioclase and augite compositions are presented by unit in Tables 6 and 7 and in Figures 7 and 8 . The plagioclase phenocryst cores in each unit have a wide range of composition, and all four units have two populations. Units 1, 2, and 4 have a high-anorthite group of phenocrysts with cores of $\mathrm{An}_{82-88}$ and another group with cores in the range of $\mathrm{An}_{60-72}$. Unit 2 may have a distinct, third group of plagioclase phenocrysts that are $\mathrm{An}_{45-60}$, but this group may be the result of zoning during slow cooling of the flow. The thickest unit (unit 3) has two distinct populations of plagioclase, but the most anorthitic are $\mathrm{An}_{76-79}$. All of the units contain glomerocrysts of plagioclase and augite, and it is these glomerocrysts that contain the feldspars with the high anorthite content. Zoning of the feldpsars is normal, with the highest anorthite values in the interiors of crystals and the lower values in the rims and groundmass.

Clinopyroxene compositions from units 2 and 3 (in particular, their Mg\#) can be grouped into two or three distinct modes similar to those of the feldspars. There are not enough data for units 1 and 4 to say whether there is a bimodal distribution of $\mathrm{Mg}$ values (Fig. 8). The possibility that three populations of augite occur in unit 2 supports the observation that three populations of plagioclase phenocryst cores may also exist in this unit (Fig. 7). Pyroxene phenocryst cores with Mg\#s of 88 or greater probably represent an earlier phase of crystallization from a more mafic liquid at higher temperatures than the host basalt.

Opaque oxide microphenocrysts were reported in unit 3 as minor constituents and in the groundmass (Backman, Duncan, et al., 1988). Skeletal and groundmass titanomagnetites were analyzed in the lower two units of the site, and they are typical of late-stage oxides with low chromium contents (Table 5). No ilmenite was found, however. Glass was not preserved in Site 707.

\section{Site 713 (Near Ridge Volcanism)}

At Site 713 on the northern edge of the Chagos Bank, about half of the $85 \mathrm{~m}$ of basement that was drilled was recovered. We 
Table 6. Microprobe analyses of plagioclase phenocrysts, Site 707.

\begin{tabular}{|c|c|c|c|c|c|c|c|c|c|c|c|c|c|}
\hline $\begin{array}{l}\text { Hole no. } \\
\text { Unit no. } \\
\text { Core, section } \\
\text { Interval (cm) } \\
\text { Depth (mbsf) } \\
\text { Analysis }\end{array}$ & $\begin{array}{l}707 \mathrm{C} \\
1 \\
22 \mathrm{R}-1 \\
94-95 \\
376.54 \\
1\end{array}$ & 2 & 3 & $\begin{array}{l}707 \mathrm{C} \\
1 \\
22 \mathrm{R}-2 \\
37-38 \\
377.57 \\
1\end{array}$ & 2 & $\begin{array}{l}707 \mathrm{C} \\
2 \\
23 \mathrm{R}-1 \\
24-25 \\
385.54 \\
1\end{array}$ & 2 & $\begin{array}{l}707 C \\
2 \\
23 R-1 \\
65-66 \\
385.95 \\
1\end{array}$ & 2 & 3 & $\begin{array}{l}707 \mathrm{C} \\
2 \\
23 \mathrm{R}-3 \\
137-140 \\
389.67 \\
1\end{array}$ & 2 & 3 \\
\hline $\begin{array}{l}\mathrm{SiO}_{2} \\
\mathrm{Al}_{2} \mathrm{O}_{3} \\
\mathrm{FeO} \\
\mathrm{CaO} \\
\mathrm{Na}_{2} \mathrm{O} \\
\mathrm{K}_{2} \mathrm{O}\end{array}$ & $\begin{array}{r}46.44 \\
34.09 \\
0.62 \\
18.35 \\
1.36 \\
0.07\end{array}$ & $\begin{array}{r}49.36 \\
31.00 \\
0.87 \\
15.15 \\
3.27 \\
0.07\end{array}$ & \begin{tabular}{r|}
53.27 \\
28.28 \\
1.14 \\
12.06 \\
4.88 \\
0.07
\end{tabular} & $\begin{array}{r}50.76 \\
30.22 \\
0.68 \\
14.51 \\
2.79 \\
0.05\end{array}$ & $\begin{array}{r}55.29 \\
27.52 \\
1.84 \\
11.45 \\
4.86 \\
0.07\end{array}$ & $\begin{array}{r}45.60 \\
34.02 \\
0.61 \\
18.42 \\
1.41 \\
0.07\end{array}$ & $\begin{array}{r}45.12 \\
33.36 \\
0.74 \\
17.84 \\
1.67 \\
0.07\end{array}$ & $\begin{array}{r}56.41 \\
25.82 \\
1.05 \\
9.52 \\
6.58 \\
0.05\end{array}$ & $\begin{array}{r}49.42 \\
30.55 \\
0.69 \\
14.63 \\
2.91 \\
0.04\end{array}$ & $\begin{array}{r}50.82 \\
29.12 \\
1.00 \\
12.86 \\
4.31 \\
0.05\end{array}$ & $\begin{array}{r}47.66 \\
33.51 \\
0.63 \\
17.22 \\
1.92 \\
0.04\end{array}$ & $\begin{array}{r}50.46 \\
30.23 \\
0.82 \\
15.33 \\
3.07 \\
0.04\end{array}$ & $\begin{array}{r}54.18 \\
27.23 \\
1.02 \\
11.28 \\
5.76 \\
0.04\end{array}$ \\
\hline Total & 100.92 & 99.71 & 99.69 & 99.01 & 101.03 & 100.12 & 98.81 & 99.42 & 98.24 & 98.17 & 100.98 & 99.95 & 99.51 \\
\hline $\begin{array}{l}\text { An } \\
\text { Notes }\end{array}$ & $\begin{array}{c}88.0 \\
\text { c }\end{array}$ & $\begin{array}{c}71.7 \\
r\end{array}$ & $\begin{array}{c}57.6 \\
\mathrm{~m}\end{array}$ & $\begin{array}{c}74.0 \\
\text { c }\end{array}$ & $\begin{array}{c}56.4 \\
r\end{array}$ & $\begin{array}{c}87.6 \\
c\end{array}$ & $\begin{array}{c}85.3 \\
r\end{array}$ & $\begin{array}{c}44.3 \\
r\end{array}$ & $\begin{array}{c}73.4 \\
c\end{array}$ & $\begin{array}{c}62.1 \\
\mathrm{r}\end{array}$ & $\begin{array}{c}83.1 \\
c\end{array}$ & $\begin{array}{c}73.3 \\
\mathrm{r}\end{array}$ & $\begin{array}{c}51.9 \\
\mathrm{~m}\end{array}$ \\
\hline
\end{tabular}

\begin{tabular}{|c|c|c|c|c|c|c|c|c|c|}
\hline $\begin{array}{l}\text { Hole no. } \\
\text { Unit no. } \\
\text { Core, section } \\
\text { Interval (cm) } \\
\text { Depth (mbsf) } \\
\text { Analysis }\end{array}$ & $\begin{array}{l}707 \mathrm{C} \\
3 \\
25 \mathrm{R}-3 \\
0-1 \\
407.5 \\
1\end{array}$ & 2 & $\begin{array}{l}707 \mathrm{C} \\
3 \\
26 \mathrm{R}-2 \\
126-128 \\
417.06 \\
1\end{array}$ & 2 & $\begin{array}{l}707 \mathrm{C} \\
4 \\
28 \mathrm{R}-1 \\
27-29 \\
433.87 \\
1\end{array}$ & 2 & $\begin{array}{l}707 \mathrm{C} \\
4 \\
28 \mathrm{R}-3 \\
48-50 \\
437.08 \\
1\end{array}$ & 2 & 3 \\
\hline $\mathrm{SiO}_{2}$ & 50.59 & 53.17 & 50.03 & 48.43 & 50.82 & 51.87 & 51.95 & 46.30 & 57.38 \\
\hline $\mathrm{Al}_{2} \mathrm{O}_{3}$ & 29.51 & 29.68 & 31.32 & 32.07 & 30.74 & 30.41 & 29.14 & 33.62 & 25.92 \\
\hline $\mathrm{FeO}$ & 0.79 & 0.95 & 0.72 & 0.82 & 0.74 & 0.71 & 0.99 & 0.62 & 0.88 \\
\hline $\mathrm{CaO}$ & 14.34 & 13.63 & 16.04 & 16.43 & 14.98 & 14.72 & 12.88 & 17.44 & 9.33 \\
\hline $\mathrm{Na}_{2} \mathrm{O}$ & 3.22 & 4.45 & 2.71 & 2.25 & 3.40 & 3.37 & 3.66 & 1.35 & 6.15 \\
\hline $\mathrm{K}_{2} \mathrm{O}$ & 0.11 & 0.07 & 0.06 & 0.05 & 0.06 & 0.05 & 0.04 & 0.04 & 0.05 \\
\hline Total & 98.55 & 101.95 & 100.88 & 100.05 & 100.74 & 101.14 & 98.66 & 99.38 & 99.71 \\
\hline An & 70.7 & 62.6 & 76.3 & 79.9 & 70.7 & 70.5 & 65.9 & 87.6 & 45.5 \\
\hline Notes & c & $\mathrm{r}$ & c & $r$ & c & $\mathrm{r}$ & $r$ & c & $\mathrm{m}$ \\
\hline
\end{tabular}

Notes: $\mathrm{c}=$ core, $\mathrm{r}=\operatorname{rim}$, and $\mathrm{m}=$ microphenocryst.

identified 35 flows; of these, the upper 11 flows extend from the basement/sediment contact at $107 \mathrm{~m}$ to $174 \mathrm{mbsf}$. The lower 23 flows make up only $17 \mathrm{~m}$ of the hole from 174 to $191 \mathrm{mbsf}$.

\section{Chemistry}

Three chemical units were identified in these flows based on major and trace element chemistry (Fig. 4). Units 1 and 2 have higher $\mathrm{Fe}_{2} \mathrm{O}_{3}, \mathrm{TiO}_{2}, \mathrm{P}_{2} \mathrm{O}_{5}, \mathrm{Zr}, \mathrm{Ba}$, and $\mathrm{Y}$ values than unit 3, yet units 1 and 2 can be distinguished by their $\mathrm{Al}_{2} \mathrm{O}_{3}$ (not shown) and $\mathrm{Sr}$ abundances. The abundance of $\mathrm{MgO}$ is fairly constant (6-8 wt\%) throughout all units (Backman, Duncan, et al., 1988), so the wide range in trace element abundances implies that the upper 2 units and lower unit are not simply related by fractional crystallization. Also present at Site 713 is an iron-titanium-rich glass from a turbidite between units 2 and 3 . This glass can be considered a fourth chemical unit that was derived from the others by fractional crystallization.

\section{Mineralogy}

Plagioclase phenocrysts are usually the dominant mineral phase in the basalts at Site 713 , and they vary from 2 to 25 modal $\%$ in the upper lavas and from 4 to 30 modal $\%$ in the lower flows. Pyroxene (1-40 modal \% in units 1 and 2 , and 3-13 modal $\%$ in unit 3 ) is the second most common phenocryst phase, except in some of the upper flows where it exceeds plagioclase in abundance. Olivine pseudomorphs are present in the majority of the flows for which thin sections were made, and they always represent $<5 \%$ of the sample. The groundmass invariably consists of plagioclase, augite, and oxides, except in the chilled margins of flows where the groundmass can be entirely glass or a mixture of groundmass minerals and glass.

\section{Alteration}

As at Sites 706 and 707, alteration occurs throughout the section. At Site 713 the upper flows have experienced $1 \%-65 \%$ alteration based on visual estimates from thin sections. Samples with small amounts of alteration are glassy. In the lower flows, alteration varies from $10 \%$ to $85 \%$, yet in some samples with $50 \%$ alteration, primary olivine and glass are preserved.

\section{Mineral Chemistry}

We analyzed 13 thin sections from the three units from Site 713 , and the results are presented in Tables 5, 8, 9, 10, and 11. As in Sites 706 and 707, the feldspars have a wide range of anorthite content in all three units, and there appears to be at least two distinct chemical groups (Fig. 9). The high-anorthite plagioclase analyses are commonly found in the cores of the larger phenocrysts, and the lower anorthite plagioclase is found in the glomerocrysts. The few augite analyses do not appear to fall into groups based on $\mathrm{Mg} \#$ (Fig. 10). The cores of the pyroxene phenocrysts have higher $\mathrm{Cr}_{2} \mathrm{O}_{3}$ and less $\mathrm{TiO}_{2}$ and $\mathrm{Al}_{2} \mathrm{O}_{3}$ than the rims of the same grains (Table 9). The high $\mathrm{Cr}$ and $\mathrm{Mg \#}$ suggest that the cores represent an earlier stage of crystallization at high temperatures, possibly from a magma with higher $\mathrm{Cr}_{2} \mathrm{O}_{3}$. The $\mathrm{TiO}_{2}$ contents of the rims reach $1.6 \mathrm{wt} \%$, which is typical of titanaugites from alkali basalts but not as high as the $\mathrm{TiO}_{2}$ found in the rims of pyroxenes in the upper units of Site 706 .

Glass was preserved in several of the flows at Site 713. No glass was found in chemical unit 1 . In chemical unit 2 the only glass (Table 10) has low total abundance of the oxides, low $\mathrm{Na}_{2} \mathrm{O}$ content, and a variable composition. This unit has only a small amount of alteration, but the glass may have started to de- 
Table 7. Microprobe analyses of clinopyroxenes, Site 707 .

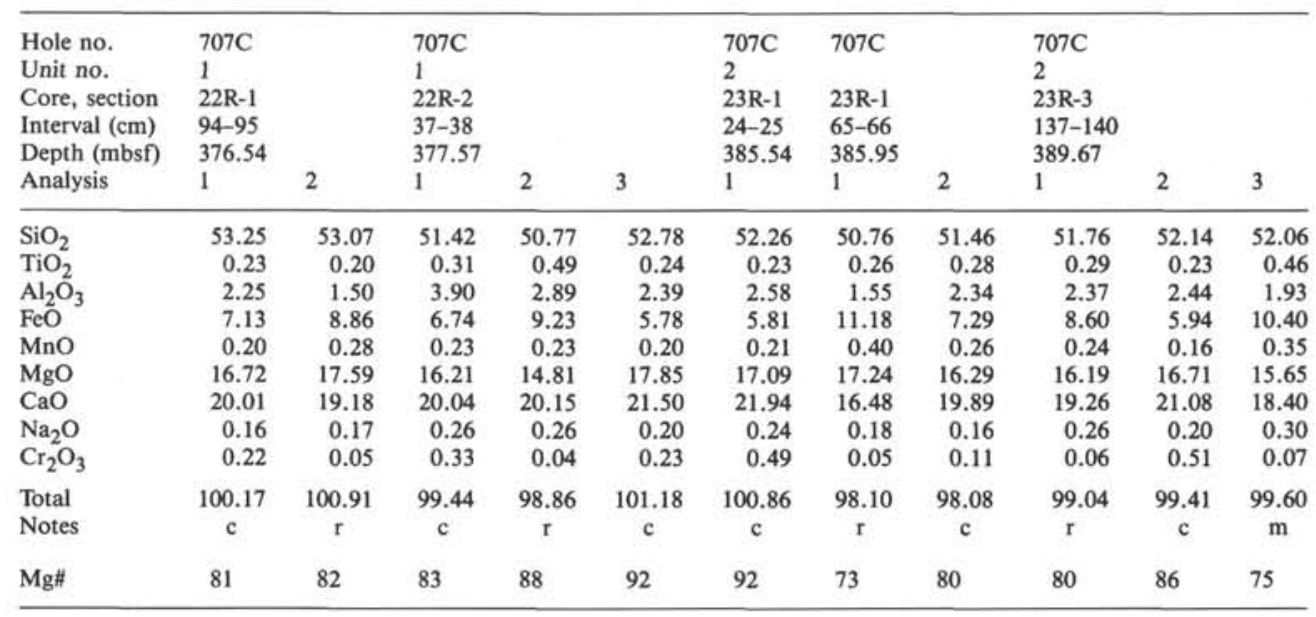

\begin{tabular}{|c|c|c|c|c|c|c|c|}
\hline $\begin{array}{l}\text { Hole no. } \\
\text { Unit no. } \\
\text { Core, section } \\
\text { Interval (cm) } \\
\text { Depth (mbsf) } \\
\text { Analysis }\end{array}$ & $\begin{array}{l}707 \mathrm{C} \\
3 \\
26 \mathrm{R}-2 \\
126-128 \\
417.06 \\
1\end{array}$ & 2 & 3 & $\begin{array}{l}707 \mathrm{C} \\
4 \\
28 \mathrm{R}-3 \\
48-50 \\
437.08 \\
1\end{array}$ & 2 & 3 & 4 \\
\hline $\mathrm{SiO}_{2}$ & 51.78 & 51.37 & 52.11 & 51.09 & 50.77 & 51.37 & 52.71 \\
\hline $\mathrm{TiO}_{2}$ & 0.50 & 0.51 & 0.41 & 0.16 & 0.25 & 0.31 & 0.22 \\
\hline $\mathrm{Al}_{2} \mathrm{O}_{3}$ & 2.98 & 2.52 & 2.06 & 2.63 & 2.42 & 3.35 & 1.88 \\
\hline $\mathrm{FeO}$ & 9.10 & 8.75 & 10.57 & 5.62 & 7.17 & 6.78 & 6.95 \\
\hline $\mathrm{MnO}$ & 0.24 & 0.21 & 0.27 & 0.15 & 0.21 & 0.21 & 0.18 \\
\hline $\mathrm{MgO}$ & 15.45 & 16.33 & 16.73 & 16.85 & 16.84 & 16.41 & 16.41 \\
\hline $\mathrm{CaO}$ & 18.26 & 19.48 & 18.21 & 21.76 & 20.75 & 20.95 & 19.96 \\
\hline $\mathrm{Na}_{2} \mathrm{O}$ & 0.31 & 0.30 & 0.22 & 0.28 & 0.20 & 0.22 & 0.15 \\
\hline $\mathrm{Cr}_{2} \mathrm{O}_{3}$ & 0.07 & 0.23 & 0.08 & 0.34 & 0.05 & 0.24 & 0.05 \\
\hline Total & 98.68 & 99.70 & 100.66 & 98.89 & 98.66 & 99.85 & 98.51 \\
\hline Notes & $\mathrm{m}$ & c & $r$ & c & $\mathrm{r}$ & c & $\mathrm{r}$ \\
\hline Mg\# & 75 & 82 & 88 & 94 & 89 & 87 & 81 \\
\hline
\end{tabular}

Notes: $\mathrm{c}=$ core, $\mathrm{r}=$ rim, and $\mathrm{m}=$ microphenocryst.
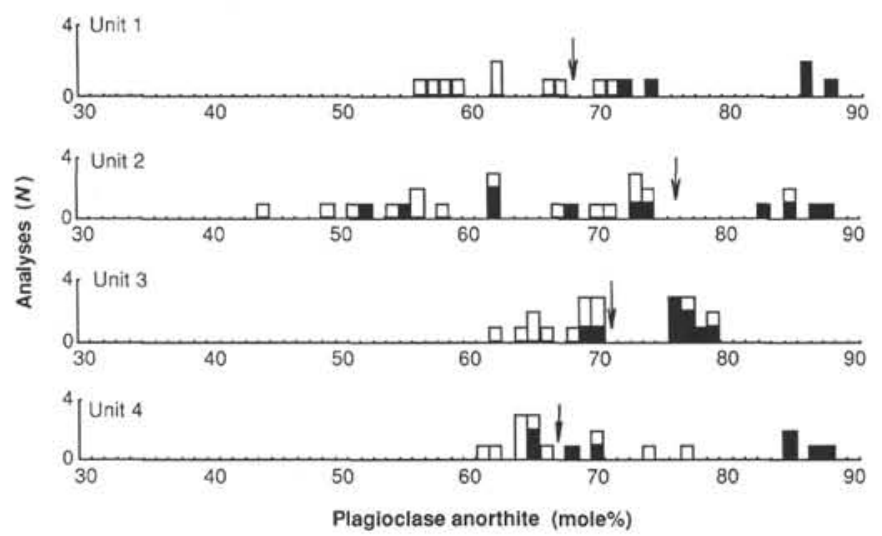

Figure 7. Histogram of the anorthite content of plagioclase in the four chemical units at Site 707. Units 1 and 2 have a wide range of compositions even though each unit is a single flow. All chemical units contain plagioclase with anorthite content too high to have crystallized from the host magma.

vitrify and hydrate. In chemical unit 3 , glass is preserved in many of the flows. This glass is chemically uniform throughout the $22 \mathrm{~m}$ of this unit, and the standard deviation of the average of most elements is within the analytical error of the micro-

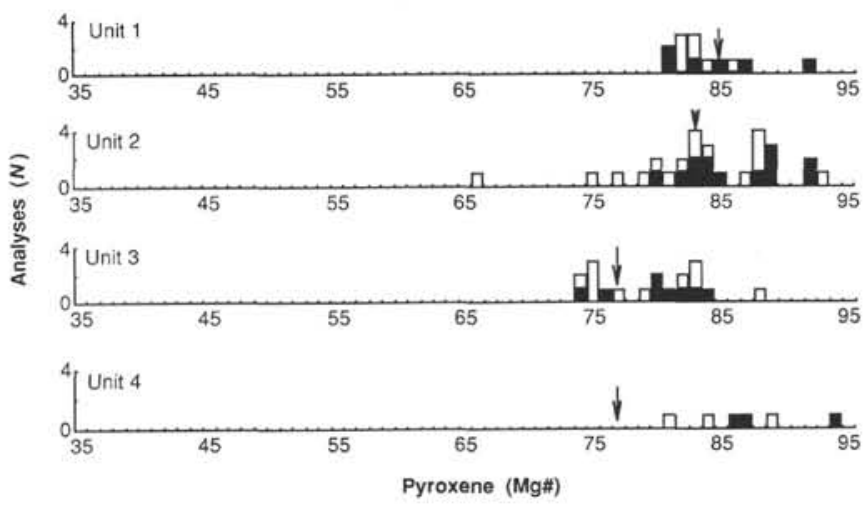

Figure 8. Histogram of magnesium-augite Mg\# for Site 707 chemical units. The pyroxene analyses have a restricted range of compositions compared with plagioclase of the same units. All units have one or more pyroxene analyses with unusually high $\mathrm{Mg} \#$ compared with that expected, given the composition of the host magmas.

probe. The glass found in the volcanic turbidite between units 2 and 3 is clearly different from any of the other Site 713 units (Figs. 3 and 4) and could be classified as a Fe-Ti basalt. Quenched olivine $\left(\mathrm{Fo}_{82}\right.$; Table 11$)$ is preserved in the glassy margins of the many thin flows in unit 3 . 
Table 8. Microprobe analyses of plagioclase phenocrysts, Site 713.

\begin{tabular}{|c|c|c|c|c|c|c|c|c|c|}
\hline $\begin{array}{l}\text { Hole no. } \\
\text { Unit no. } \\
\text { Core, section } \\
\text { Interval (cm) } \\
\text { Depth (mbsf) } \\
\text { Analysis no. }\end{array}$ & $\begin{array}{l}713 \mathrm{~A} \\
1 \\
13 \mathrm{R}-3 \\
16-20 \\
110.86 \\
1\end{array}$ & 2 & $\begin{array}{l}713 \mathrm{~A} \\
2 \\
15 \mathrm{R}-4 \\
44-46 \\
131.64 \\
1\end{array}$ & $\begin{array}{l}713 \mathrm{~A} \\
2 \\
15 \mathrm{R}-4 \\
143-145 \\
132.63 \\
1\end{array}$ & 2 & $\begin{array}{l}713 \mathrm{~A} \\
2 \\
15 \mathrm{R}-4 \\
3-7 \\
132.73 \\
1\end{array}$ & 2 & 3 & 4 \\
\hline $\begin{array}{l}\mathrm{SiO}_{2} \\
\mathrm{Al}_{2} \mathrm{O}_{3} \\
\mathrm{FeO} \\
\mathrm{CaO} \\
\mathrm{Na}_{2} \mathrm{O} \\
\mathrm{K}_{2} \mathrm{O}\end{array}$ & $\begin{array}{r}45.80 \\
33.98 \\
0.67 \\
17.73 \\
1.71 \\
0.05\end{array}$ & $\begin{array}{r}46.11 \\
32.03 \\
0.73 \\
16.38 \\
3.56 \\
0.05\end{array}$ & $\begin{array}{r}58.20 \\
25.79 \\
0.68 \\
8.57 \\
7.63 \\
0.15\end{array}$ & $\begin{array}{r}51.29 \\
30.42 \\
0.88 \\
14.04 \\
3.98 \\
0.09\end{array}$ & $\begin{array}{r}50.13 \\
30.51 \\
0.91 \\
14.81 \\
3.64 \\
0.07\end{array}$ & $\begin{array}{r}46.89 \\
33.46 \\
0.66 \\
16.37 \\
2.06 \\
0.04\end{array}$ & $\begin{array}{r}51.15 \\
30.22 \\
1.00 \\
13.94 \\
4.07 \\
0.08\end{array}$ & $\begin{array}{r}45.27 \\
33.56 \\
0.47 \\
17.30 \\
1.59 \\
0.04\end{array}$ & $\begin{array}{r}51.80 \\
30.21 \\
0.98 \\
13.18 \\
4.27 \\
0.05\end{array}$ \\
\hline Total & 99.94 & 97.87 & 101.01 & 100.70 & 100.07 & 99.49 & 100.46 & 98.23 & 100.49 \\
\hline $\begin{array}{l}\text { An } \\
\text { Notes }\end{array}$ & $\begin{array}{c}85.1 \\
\text { c }\end{array}$ & $\begin{array}{c}77.8 \\
\mathrm{r}\end{array}$ & $\begin{array}{r}38 \\
\mathrm{r}\end{array}$ & $\begin{array}{c}65.8 \\
c\end{array}$ & $\begin{array}{r}69 \\
r\end{array}$ & $\begin{array}{r}81 \\
\mathrm{c}\end{array}$ & $\begin{array}{r}65 \\
r\end{array}$ & $\begin{array}{c}85.6 \\
r\end{array}$ & $\begin{array}{c}63 \\
\mathrm{~m}\end{array}$ \\
\hline
\end{tabular}

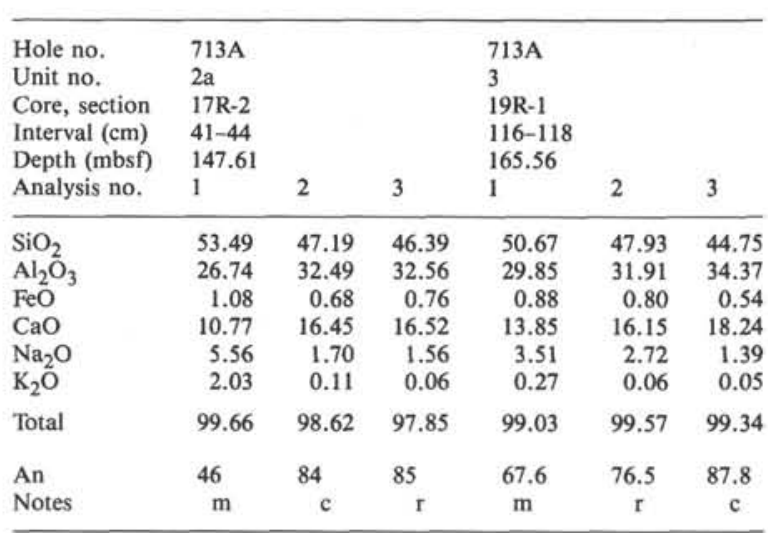

Notes: $\mathrm{c}=$ core, $\mathrm{r}=\operatorname{rim}$, and $\mathrm{m}=$ microphenocryst.

\section{Site 715 (Analogous to Réunion)}

Site 715 was drilled on the eastern side of the Maldive Islands platform in $2266 \mathrm{~m}$ of water. About $75 \mathrm{~m}$ of basalt was drilled, and 21 flows were identified, some of which were separated by carbonate sediments.

\section{Chemistry}

Three units at Site 715 can be distinguished compositionally. The uppermost unit is made up of $\mathrm{Fe}$ - $\mathrm{Ti}$ basalts with greater than $12 \mathrm{wt} \%$ total FeO (Fig. 4) and with alkali abundance that places it in the alkali basalt field (Fig. 3B). This unit overlies 50 $\mathrm{cm}$ of carbonate sediment that separates it from units with lower $\mathrm{FeO}$. The lower two units are made up of primitive flows with more than $9 \mathrm{wt} \% \mathrm{MgO}$, which are classified as tholeiites based on alkali and silica abundances (Fig. 3B). Flows 9 and 10 have subtle chemical signatures (in $\mathrm{Zr}, \mathrm{Sr}, \mathrm{Nb}$, and $\mathrm{Cr}$ ) that distinguish them from flows 12 through 21 (Fig. 4; Backman, Duncan, et al., 1988). These chemical differences could be caused by fractional crystallization, in which case, all of the magmas may be derived from a common parent.

\section{Mineralogy}

The upper flows (1-7; chemical unit 1), including the Fe-Ti basalts, are nearly aphyric and contain 1\%-3\% (modal) plagioclase phenocrysts, which are $>2 \mathrm{~mm}$ at their greatest dimension. Olivine and augite are rare. Flows 9, 10, and 11 (chemical unit 2) are olivine phyric, with original olivine contents up to 15 modal $\%$, but they do not contain any plagioclase or augite. In chemical unit 3, flow 12 has $10 \%$ olivine and $20 \%$ plagioclase, and flow 13 had $10 \%$ olivine. Flows 14 through 21 are mostly aphyric.
Throughout the site, the groundmass of these flows is either glass (flow 12) or plagioclase, augite, opaques, and olivine.

\section{Alteration}

The rocks throughout the hole are pervasively altered, and all glass and olivine are replaced with clay. Often the olivine is replaced by iddingsite. In some of the flows, plagioclase and augite are partially replaced by clays. The opaques, however, seem unaffected. Alteration products constitute $10 \%-90 \%$ of the flows studied in thin section.

\section{Mineral Chemistry}

Eight thin sections representing the three chemically distinct units were examined by microprobe (Tables 5, 12, 13, and 14), and it was found that their phenocrysts are also chemically distinctive. The cores of the feldspars in unit 1 have a maximum $\mathrm{An}_{70}$ content, whereas units 2 and 3 have phenocrysts with cores of $\mathrm{An}_{76}$ and $\mathrm{An}_{79}$, respectively (Fig. 11). The feldspars in units 1 and 2 have normal zoning, but those in unit 3 have both normal and reversed zoning. Pyroxene from the three units at Site 715 is also distinctive (Fig. 12). Unit 1 does not contain the high-MgO phenocrysts that are found in units 2 and 3 . The $\mathrm{Cr}_{2} \mathrm{O}_{3}$ in phenocryst cores from units 2 and 3 is as high as $0.9 \mathrm{wt} \%$, whereas augite cores in unit 1 have $0.1 \mathrm{wt} \%$ or less.

Olivine was originally present in all three units, but it is preserved only in flow 18 of chemical unit 3; its composition is $\mathrm{Fo}_{72-81}$ (Table 14). Glass was originally present in the margins of some of the flows, but it was altered to clay in all of the thin sections that were examined. Groundmass oxide minerals in the upper unit are both magnetite and ilmenite, but in the lower two units they are primarily magnetite. 
Table 9. Microprobe analyses of clinopyroxenes, Site 713.

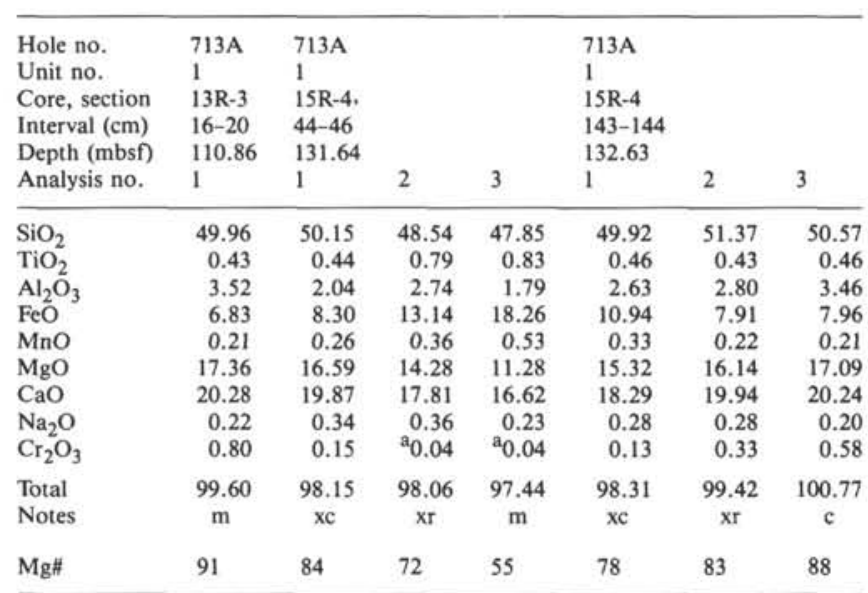

\begin{tabular}{|c|c|c|c|c|c|c|c|}
\hline $\begin{array}{l}\text { Hole no. } \\
\text { Unit no. } \\
\text { Core, section } \\
\text { Interval (cm) } \\
\text { Depth (mbsf) } \\
\text { Analysis no. }\end{array}$ & $\begin{array}{l}713 \mathrm{~A} \\
2 \\
15 \mathrm{R}-5 \\
3-7 \\
132.73 \\
1\end{array}$ & 2 & 3 & 4 & $\begin{array}{l}713 \mathrm{~A} \\
3 \\
19 \mathrm{R}-1 \\
116-118 \\
165.56 \\
1\end{array}$ & 2 & 3 \\
\hline $\mathrm{SiO}_{2}$ & 51.13 & 51.09 & 53.25 & 52.35 & 51.42 & 51.34 & 49.91 \\
\hline $\mathrm{TiO}_{2}$ & 0.42 & 0.54 & 0.34 & 0.45 & 0.41 & 0.26 & 0.81 \\
\hline $\mathrm{Al}_{2} \mathrm{O}_{3}$ & 2.31 & 2.82 & 2.45 & 2.88 & 4.07 & 2.58 & 5.31 \\
\hline $\mathrm{FeO}$ & 7.51 & 8.82 & 7.98 & 8.70 & 5.75 & 5.55 & 7.44 \\
\hline $\mathrm{MnO}$ & 0.20 & 0.29 & 0.25 & 0.26 & 0.15 & 0.13 & 0.17 \\
\hline $\mathrm{MgO}$ & 16.55 & 15.22 & 17.13 & 16.38 & 16.86 & 16.62 & 15.09 \\
\hline $\mathrm{CaO}$ & 19.32 & 18.32 & 18.18 & 17.73 & 20.43 & 21.50 & 20.51 \\
\hline $\mathrm{Na}_{2} \mathrm{O}$ & 0.29 & 0.32 & 0.33 & 0.28 & 0.24 & 0.23 & 0.26 \\
\hline $\mathrm{Cr}_{2} \mathrm{O}_{3}$ & 0.46 & 0.17 & 0.38 & 0.26 & 0.56 & 0.30 & 0.07 \\
\hline Total & 98.19 & 97.58 & 100.31 & 99.30 & 99.90 & 98.51 & 99.58 \\
\hline Notes & c & r & c & r & c & $r$ & $\mathrm{~m}$ \\
\hline $\mathrm{Mg \#}$ & 84 & 75 & 79 & 77 & 87 & 90 & 82 \\
\hline
\end{tabular}

Notes: $\mathrm{c}=$ core, $\mathrm{r}=\mathrm{rim}, \mathrm{m}=$ microphenocryst, $\mathrm{xc}=$ xenocryst core, and $\mathrm{xr}=$ xenocryst rim.

a Minimum detection limit for $\mathrm{Cr}_{2} \mathrm{O}_{3}$ is $0.04 \mathrm{wt} \%$.

\section{DISCUSSION}

\section{Site 706}

The chemistry of phenocrysts in Site 706 basalts is consistent with the bulk chemistry of the units. For example, chemical units 1 and 2 have lower average $\mathrm{CaO} / \mathrm{Na}_{2} \mathrm{O}$ and $\mathrm{Al}_{2} \mathrm{O}_{3}$ (Fig. 13) than unit 3. This corresponds to the lower anorthite content of the feldspars in units 1 and 2 (Fig. 5). The low $\mathrm{MgO} / \mathrm{FeO}$ of the upper two units is also reflected in the lower average $\mathrm{MgO} / \mathrm{FeO}$ of the pyroxenes in these units (Fig. 6).

The compositions of the majority of the phenocrysts in these rocks are close to the calculated equilibrium compositions based on the phase equilibrium model for basaltic magmas (Nielsen, 1988). The compositions of olivine, plagioclase, and augite at the liquidus temperature of each of the three chemical units at Site 706 are given in Table 15. Based on the ability of this model to predict the chemistry of minerals crystallizing from basalts (Nielsen, 1988), these calculated mineral compositions are accurate to within $\pm 5 \%$ and are therefore useful in determining if minerals could have crystallized from the host magma or if they are xenocrysts or xenoliths.

In chemical units 1 (flows 1-21) and 2 (flows 22-30), the median value of plagioclase core and rim compositions is $\mathrm{An}_{60}$, and the calculated equilibrium values are $\mathrm{An}_{61}$ and $\mathrm{An}_{62}$, respectively. The similarity of the calculated equilibrium plagioclase and the observed plagioclase of units 1 and 2 suggests that, for the most part, these 30 flows erupted from a magma chamber with temperatures as high as $1143^{\circ} \mathrm{C}$. This is possible if the influx of parental magma is balanced by the amount of crystallization and eruption.

The few plagioclase phenocrysts that are $\mathrm{An}_{70}$ or greater are in the cores of rare, large phenocrysts from flow 3 near the top of chemical unit 1 , or from flows 18 and 20 near the base of unit 1 . Only one thin section from chemical unit 2 (flow 28) was analyzed, but it also had rare, large plagioclase phenocrysts with cores of $\mathrm{An}_{70-72}$. All of these phenocrysts are strongly zoned to rims of about $\mathrm{An}_{60}$. These cores must have crystallized from a magma that was more primitive than the bulk of the magma at this site.

It appears from the plagioclase and bulk-rock compositions of the upper two units that the magma chamber and mineralogy remained at a steady state while the uppermost 30 flows were erupted. The presence of plagioclase phenocryst cores $\left(\mathrm{An}_{70}\right.$ or greater) in several flows indicates that these flows contained an admixed component that was either another magma of a different composition (and higher temperature or water content) or that the plagioclase was picked up from the magma chamber walls, from the conduit during eruption, or from a region of the magma chamber that had a higher temperature than the bulk of the erupted magma.

The chemical composition and mineralogy of chemical unit 3 (flows 31 and 32 and Fig. 4) distinguishes it from the 30 flows above it. Unit 3 is noted for its abundant (15\%), large, plagioclase phenocrysts (Backman, Duncan, et al., 1988) with cores of $\mathrm{An}_{83-88}$ and rims of $\mathrm{An}_{70}$. The anorthite content of the cores is higher than the equilibrium value calculated for the bulk composition of the unit $\left(\mathrm{An}_{77}\right.$; Table 15). This difference could be caused by the mixing of a magma that contained high-An plagioclase $\left(\mathrm{An}_{83-88}\right)$ with a magma that was crystallizing plagioclase of $\mathrm{An}_{70}$. The bulk composition of the resulting mix could have a composition that would crystallize $\mathrm{An}_{77}$ plagioclase.

The calculated equilibrium pyroxene composition for chemical units 1 and 2 are nearly identical (Table 15). The $\mathrm{Mg}^{+}(100$ $\mathrm{En} /[\mathrm{En}+\mathrm{Fs}])$ of these pyroxenes is 72 and 74 , respectively. Because the model assumes all the iron in the pyroxene is $\mathrm{FeO}$, this value will be slightly lower than the $\mathrm{Mg} \#$ of the pyroxene analyses plotted in Figure 6, because the ferrous iron in the microprobe analyses has been adjusted for the stoichiometry of the pyroxenes and for preferred site occupancy based on the model of Papike et al. (1974). Even though there are slight differences in calculating the $\mathrm{Mg} \#$ of the microprobe analyses and the pyroxenes discussed above, we conclude that the majority of the pyroxene phenocrysts and microphenocrysts crystallized near the liquidus temperature of their host magmas.

Some augite phenocrysts in unit 1 (Fig. 6) have an exceptionally high $\mathrm{Mg \#} \mathrm{(86} \mathrm{or} 88)$. These occur in the topmost sample in Hole 706B as well as in flow 3 near the top of chemical unit 1 . This same flow has plagioclase phenocryst cores with high anorthite content (Fig. 5), which supports the hypothesis that some of the flows represent magmas with an admixed mafic component. Whether this admixed component is a second magma with high-temperature plagioclase and pyroxene phenocrysts or is a disrupted gabbroic cumulate from the margins of the magma chamber is not clear.

The similarity of the plagioclase and pyroxene equilibrium temperatures for units 1 and 2 (Table 15) supports the hypothesis that these two phases crystallized together in a steady-state magma chamber at $1130^{\circ}-1143^{\circ} \mathrm{C}$. The order of crystallization of primitive Réunion Island magmas at 1 atm is olivine first, followed by plagioclase, and then augite (Fisk et al., 1988). At $1150^{\circ}-1160^{\circ} \mathrm{C}$ all three phases crystallize together, but below 
Table 10. Microprobe analyses of glasses, Site 713.

\begin{tabular}{|c|c|c|c|c|c|c|c|c|c|}
\hline $\begin{array}{l}\text { Hole no. } \\
\text { Unit no. } \\
\text { Core, section } \\
\text { Interval }(\mathrm{cm}) \\
\text { Depth (mbsf) } \\
\text { Average }(N)\end{array}$ & $\begin{array}{l}713 \mathrm{~A} \\
2 \\
15 \mathrm{R}-5 \\
3-7 \\
133.00 \\
2\end{array}$ & $\begin{array}{l}713 \mathrm{~A} \\
2 \\
15 \mathrm{R}-5 \\
3-7 \\
146.11 \\
2\end{array}$ & $\begin{array}{l}713 \mathrm{~A} \\
\overline{\mathrm{a}}^{-17 \mathrm{R}-2} \\
41-44 \\
5\end{array}$ & & & & & & \\
\hline $\begin{array}{l}\mathrm{SiO}_{2} \\
\mathrm{TiO}_{2} \\
\mathrm{Al}_{2} \mathrm{O}_{3} \\
\mathrm{FeO} \\
\mathrm{MnO} \\
\mathrm{MgO} \\
\mathrm{CaO} \\
\mathrm{Na}_{2} \mathrm{O} \\
\mathrm{K}_{2} \mathrm{O}\end{array}$ & $\begin{array}{r}44.59 \\
2.22 \\
12.18 \\
17.20 \\
0.33 \\
7.62 \\
9.34 \\
1.24 \\
0.41\end{array}$ & $\begin{array}{r}51.02 \\
1.80 \\
12.70 \\
14.22 \\
0.29 \\
5.98 \\
8.29 \\
1.16 \\
0.27\end{array}$ & $\begin{array}{r}52.50 \\
2.72 \\
12.85 \\
14.44 \\
0.27 \\
3.63 \\
7.70 \\
2.90 \\
0.70\end{array}$ & & & & & & \\
\hline Total & 95.19 & 95.77 & 97.75 & & & & & & \\
\hline $\begin{array}{l}\text { Hole no. } \\
\text { Unit no. } \\
\text { Core, section } \\
\text { Interval (cm) } \\
\text { Depth (mbsf) } \\
\text { Average }(N)\end{array}$ & $\begin{array}{l}713 \mathrm{~A} \\
3 \\
19 \mathrm{R}-1 \\
15-20 \\
164.55 \\
6\end{array}$ & $\begin{array}{l}713 \mathrm{~A} \\
3 \\
20 \mathrm{R}-2 \\
37-39 \\
175.77 \\
7\end{array}$ & $\begin{array}{l}713 \mathrm{~A} \\
3 \\
20 \mathrm{R}-2 \\
89-91 \\
176.29 \\
8\end{array}$ & $\begin{array}{l}713 \mathrm{~A} \\
3 \\
20 \mathrm{R}-3 \\
64-66 \\
177.54 \\
6\end{array}$ & $\begin{array}{l}713 \mathrm{~A} \\
3 \\
20 \mathrm{R}-5 \\
98-99 \\
180.88 \\
6\end{array}$ & $\begin{array}{l}713 \mathrm{~A} \\
3 \\
20 \mathrm{R}-6 \\
22-24 \\
181.62 \\
7\end{array}$ & $\begin{array}{l}713 \mathrm{~A} \\
3 \\
21 \mathrm{R}-2 \\
130-132 \\
186.10 \\
6\end{array}$ & $\begin{array}{l}713 \text { A } \\
3 \\
\text { Unit } 3 \\
\text { Ave. } \\
7\end{array}$ & $\begin{array}{l}713 \mathrm{~A} \\
3 \\
\text { Unit } 3 \\
\text { SD } \\
-\end{array}$ \\
\hline $\begin{array}{l}\mathrm{SiO}_{2} \\
\mathrm{TiO}_{2} \\
\mathrm{Al}_{2} \mathrm{O}_{3} \\
\mathrm{FeO} \\
\mathrm{MnO} \\
\mathrm{MgO} \\
\mathrm{CaO} \\
\mathrm{Na}_{2} \mathrm{O} \\
\mathrm{K}_{2} \mathrm{O}\end{array}$ & $\begin{array}{r}49.24 \\
1.10 \\
13.95 \\
11.42 \\
0.23 \\
7.43 \\
12.61 \\
2.44 \\
0.20\end{array}$ & $\begin{array}{r}49.09 \\
1.10 \\
14.07 \\
11.53 \\
0.22 \\
7.44 \\
12.82 \\
2.38 \\
0.14\end{array}$ & $\begin{array}{r}49.55 \\
1.12 \\
14.32 \\
11.66 \\
0.24 \\
7.55 \\
11.93 \\
2.39 \\
0.14\end{array}$ & $\begin{array}{r}49.92 \\
1.09 \\
14.04 \\
11.40 \\
0.21 \\
7.42 \\
12.71 \\
2.38 \\
0.13\end{array}$ & $\begin{array}{r}49.53 \\
1.12 \\
14.03 \\
11.35 \\
0.23 \\
7.47 \\
12.86 \\
2.40 \\
0.13\end{array}$ & $\begin{array}{r}48.53 \\
1.05 \\
13.95 \\
11.42 \\
0.22 \\
7.35 \\
12.42 \\
2.38 \\
0.20\end{array}$ & $\begin{array}{r}48.90 \\
1.18 \\
13.87 \\
11.40 \\
0.22 \\
7.28 \\
12.44 \\
2.46 \\
0.21\end{array}$ & $\begin{array}{r}49.25 \\
1.11 \\
14.03 \\
11.45 \\
0.22 \\
7.42 \\
12.54 \\
2.40 \\
0.16\end{array}$ & $\begin{array}{l}0.46 \\
0.04 \\
0.14 \\
0.11 \\
0.01 \\
0.09 \\
0.32 \\
0.03 \\
0.04\end{array}$ \\
\hline Total & 98.66 & 98.83 & 98.95 & 99.34 & 99.16 & 97.56 & 98.00 & & \\
\hline
\end{tabular}

Note: Ave. = average and SD = standard deviation.

${ }^{a}$ Glass in turbidite between units.

this temperature olivine reacts with the residual melt and leaves only plagioclase and augite to crystallize until the appearance of magnetite and/or ilmenite.

Figures 6 and 14A show the pyroxene $\mathrm{Mg \#}$ and quadrilateral components for augite from Site 706, and the chemical unit 3 (flows 31 and 32) augites reflect the high-MgO content of these rocks. The high-MgO contents of the augites also agree with the enstatite and ferrosilite components calculated for this unit (Table 15). The temperature at which these pyroxenes are expected to crystallize $\left(1167^{\circ} \pm 20^{\circ} \mathrm{C}\right)$ is well below the crystallization temperature calculated for plagioclase, but it is the same as the olivine crystallization temperature $\left(1152^{\circ} \mathrm{C} \pm 20^{\circ} \mathrm{C}\right)$. This indicates that the large amount of plagioclase that was found in the magma, and which appears to be out of equilibrium with the host magma, was added to the magma. The plagioclase xenocrysts are strongly zoned from $\mathrm{An}_{70-85}$, which also supports the hypotheses that these feldspars are an added component. These xenocrysts, however, have euhedral shapes and either must have overgrowths of equilibrium plagioclase or they must have been introduced into the magma shortly before the magma was quenched.

Olivine was originally present in only a few of the flows of units 1 and 2, but calculation of the equilibrium mineralogy shows that olivine is not expected to crystallize at any temperature from a magma that had a composition equivalent to the average of the 30 flows at the top of the hole (Table 15). This contradiction can be explained if the magma chamber contained a magma with only plagioclase and augite on the liquidus and this magma chamber was occasionally recharged with a primitive magma that brought olivine onto the liquidus with plagioclase and augite. Maintaining a magma chamber close to the olivine out-phase boundary long enough to erupt 30 flows (equivalent to about $70 \mathrm{~m}$ of section) requires the presence of a steady-state magma chamber. The high-An plagioclase and high-MgO pyroxene in some of the flows indicates that this magma chamber occasionally contained primitive magma that was mixed with the more evolved bulk composition, or that these plagioclase and augite xenocrysts were added to the magma by another mechanism.

\section{Site 707}

Although four chemical units can be distinguished among the five flows at Site 707 (Fig. 4), there appears to be a major change in chemistry between chemical units 2 and 3 . The upper three flows (units 1 and 2) have extremely low $\mathrm{TiO}_{2}$ content (Figs. 3A and 4E), lower than any of the Deccan lavas (Beane et al., 1986). The lower two flows (units 3 and 4) have comparatively higher $\mathrm{TiO}_{2}$ and lower $\mathrm{MgO}$ contents, similar to the Bushe flows of the Deccan province (Beane et al., 1986; Cox and Hawkesworth, 1985). The mineralogy and mineral chemistry of these units, to some extent, reflect this abrupt change in chemistry.

All units exhibit bimodal distribution of anorthite compositions (Fig. 7). The calculated equilibrium feldspar composition at the liquidus temperature is given in Table 15, and these calculated compositions are similar to the low-An plagioclase in each unit. The high-An plagioclase appears to be out of equilibrium with the bulk rock. In units 1,2 , and 4 the maximum An content of the plagioclase is 88 , but in the 40 -m-thick flow (unit 3 ) the maximum is $\mathrm{An}_{79}$. Perhaps because of the thickness of the 
Table 11. Microprobe analyses of olivine phenocrysts, Site 713.

\begin{tabular}{|c|c|c|c|c|c|c|c|c|c|c|c|c|c|}
\hline $\begin{array}{l}\text { Hole no. } \\
\text { Unit no. } \\
\text { Core, section } \\
\text { Interval (cm) } \\
\text { Depth (mbsf) } \\
\text { Analysis No. }\end{array}$ & $\begin{array}{l}713 \mathrm{~A} \\
3 \\
19 \mathrm{R}-1 \\
15-20 \\
164.55 \\
1\end{array}$ & 2 & $\begin{array}{l}713 \mathrm{~A} \\
3 \\
20 \mathrm{R}-2 \\
37-39 \\
175.77 \\
1\end{array}$ & 2 & 3 & 4 & $\begin{array}{l}713 \mathrm{~A} \\
3 \\
20 \mathrm{R}-2 \\
89-91 \\
176.29 \\
1\end{array}$ & 2 & 3 & 4 & 5 & 6 & 7 \\
\hline $\mathrm{SiO}_{2}$ & 39.27 & 37.81 & 39.73 & 39.28 & 39.00 & 39.01 & 39.69 & 39.73 & 39.51 & 39.40 & 39.29 & 39.31 & 39.45 \\
\hline $\mathrm{FeO}$ & 17.25 & 16.93 & 16.76 & 16.90 & 16.98 & 16.97 & 17.06 & 17.40 & 17.45 & 17.69 & 17.27 & 17.22 & 17.67 \\
\hline $\mathrm{MnO}$ & 0.26 & 0.27 & 0.29 & 0.26 & 0.22 & 0.32 & 0.30 & 0.32 & 0.30 & 0.27 & 0.31 & 0.32 & 0.30 \\
\hline $\mathrm{MgO}$ & 43.29 & 41.99 & 43.60 & 43.59 & 44.25 & 43.88 & 43.53 & 43.17 & 43.06 & 43.16 & 43.06 & 43.17 & 42.70 \\
\hline $\mathrm{NiO}$ & 0.09 & 0.12 & 0.12 & 0.13 & 0.15 & 0.14 & 0.12 & 0.14 & 0.09 & 0.11 & 0.09 & 0.10 & 0.14 \\
\hline Total & 100.16 & 97.13 & 100.50 & 100.08 & 100.60 & 100.32 & 100.70 & 100.74 & 100.41 & 100.63 & 100.02 & 100.12 & 100.26 \\
\hline Fo & 81.8 & 81.6 & 82.3 & 82.3 & 82.3 & 82.2 & 82 & 81.6 & 81.5 & 81.4 & 81.7 & 81.7 & 81.2 \\
\hline Notes & c & $\mathbf{r}$ & c & $\mathrm{r}$ & $\mathrm{c}$ & r & $\mathrm{m}$ & c & $\mathrm{r}$ & c & r & r & c \\
\hline
\end{tabular}

\begin{tabular}{|c|c|c|c|c|c|c|c|c|c|c|c|c|c|}
\hline $\begin{array}{l}\mathrm{SiO}_{2} \\
\mathrm{FeO} \\
\mathrm{MnO} \\
\mathrm{MgO} \\
\mathrm{NiO}\end{array}$ & $\begin{array}{r}39.44 \\
16.83 \\
0.31 \\
42.59 \\
0.11\end{array}$ & $\begin{array}{r}39.89 \\
16.61 \\
0.29 \\
42.73 \\
0.09\end{array}$ & $\begin{array}{r}39.44 \\
16.79 \\
0.30 \\
42.35 \\
0.12\end{array}$ & $\begin{array}{r}39.96 \\
16.91 \\
0.30 \\
42.39 \\
0.12\end{array}$ & $\begin{array}{r}40.18 \\
16.86 \\
0.29 \\
41.89 \\
0.19\end{array}$ & $\begin{array}{r}39.01 \\
16.59 \\
0.26 \\
42.22 \\
0.10\end{array}$ & $\begin{array}{r}40.18 \\
16.80 \\
0.26 \\
42.46 \\
0.13\end{array}$ & $\begin{array}{r}40.11 \\
16.93 \\
0.28 \\
42.51 \\
0.15\end{array}$ & $\begin{array}{r}40.32 \\
16.42 \\
0.23 \\
42.95 \\
0.12\end{array}$ & \begin{tabular}{|r|}
38.88 \\
17.08 \\
0.25 \\
42.03 \\
0.15
\end{tabular} & $\begin{array}{r}39.47 \\
16.94 \\
0.28 \\
42.32 \\
0.19\end{array}$ & $\begin{array}{r}37.94 \\
16.57 \\
0.35 \\
43.58 \\
0.19\end{array}$ & $\begin{array}{r}37.85 \\
16.92 \\
0.29 \\
43.57 \\
0.16\end{array}$ \\
\hline Total & 99.28 & 99.61 & 99.00 & 99.67 & 99.41 & 98.18 & 99.83 & 99.98 & 100.04 & 98.38 & 99.21 & 98.63 & 98.79 \\
\hline $\begin{array}{l}\text { Fo } \\
\text { Notes }\end{array}$ & $\begin{array}{r}82 \\
\mathrm{c}\end{array}$ & ${ }_{\mathrm{r}}^{82}$ & $\begin{array}{c}81.8 \\
\mathrm{~m}\end{array}$ & $\begin{array}{c}82 \\
\mathrm{~m}\end{array}$ & $\begin{array}{l}79 \\
\mathrm{c}\end{array}$ & ${ }_{\mathrm{r}}^{82}$ & $\begin{array}{r}82 \\
c\end{array}$ & $\begin{array}{r}82 \\
r\end{array}$ & $\begin{array}{r}82 \\
c\end{array}$ & $\begin{array}{c}81.7 \\
\text { r }\end{array}$ & $\begin{array}{c}81.7 \\
\mathrm{~m}\end{array}$ & $\begin{array}{c}82.4 \\
c\end{array}$ & $\begin{array}{c}82.1 \\
\text { c }\end{array}$ \\
\hline
\end{tabular}

Notes: $\mathrm{c}=$ core, $\mathrm{r}=\operatorname{rim}$, and $\mathrm{m}=$ microphenocryst.

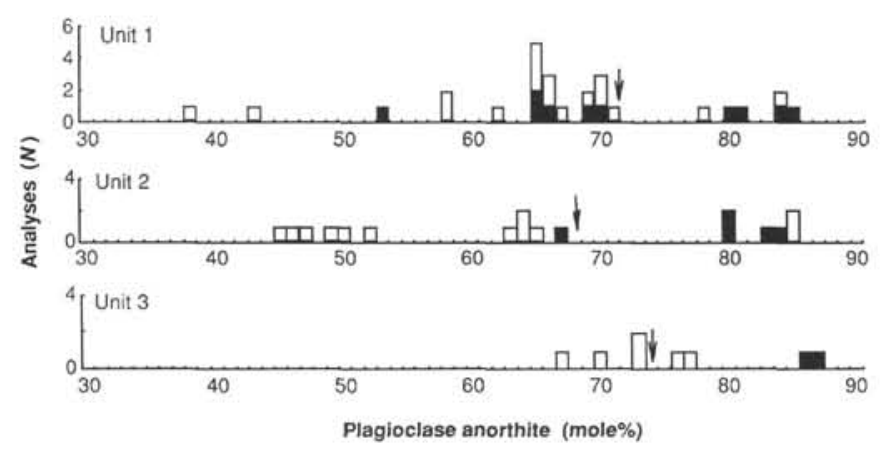

Figure 9. Histogram of anorthite content of plagioclase in Site 713 chemical units. $\mathrm{An}_{45-52}$ in unit 2 are from a volcanic turbidite between chemical units 2 and 3 and are plotted with unit 2 for convenience. Glass from this same turbidite are plotted in Figures $3 \mathrm{~A}$ and 3B.

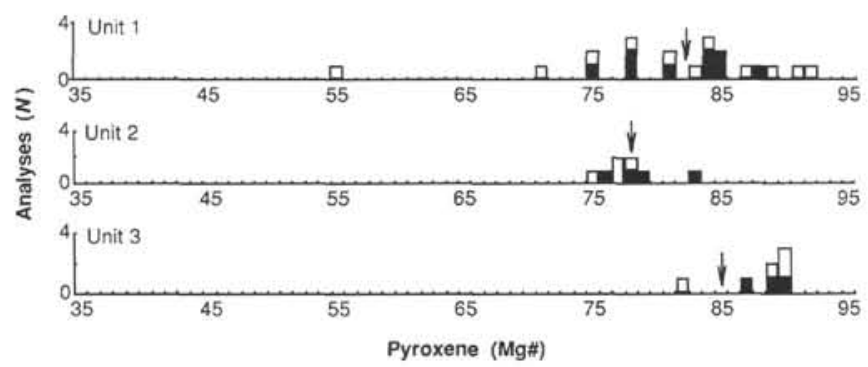

Figure 10. Histogram of magnesium-augite Mg\# from the three chemical units of Site 713. flow and its long cooling time, the plagioclase re-equilibrated during cooling, whereas the thinner flows (chemical units 1,2 , and 4) would have had their plagioclase phenocryst compositions quenched at the time of eruption.

The bimodal distribution of plagioclase compositions and the presence of plagioclase "xenocrysts" or megacrysts in all of the units implies that all of the flows have an admixed component from either a second unerupted magma or from plagioclase xenocrysts located in the magma chamber or conduit walls. If the admixed component is a magma, it will have a $\mathrm{CaO}$ / $\mathrm{Na}_{2} \mathrm{O}$ (wt\%) greater than 8 (Fisk, 1984), but in all lavas at this site the ratio is less than 6. Upper Paleocene magmas from the Indian Ocean (DSDP Site 236) with exceptionally high $\mathrm{CaO} /$ $\mathrm{Na}_{2} \mathrm{O}$ (7.6) have been reported (Melson et al., 1977), and other areas of the Indian Ocean have basalts with a $\mathrm{CaO} / \mathrm{Na}_{2} \mathrm{O}$ of 9.5 (Melson et al., 1977). The rift that produced the basalts at DSDP Site 236 (Fig. 1) is also probably the source of the basalts at Site 707 , so the primitive magmas from Site 236 could be similar to the magmas that produced the high-anorthite plagioclase in the Site 707 magmas. It is not necessary, however, that the admixed component be a magma; it could originate from the plagioclase phenocrysts that crystallized from a high- $\mathrm{CaO} / \mathrm{Na}_{2} \mathrm{O}$ magma (such as those from DSDP Site 236) and were separated from it. One mechanism for plagioclase separation could have been the plating of the magma chamber roof by floating of the feldspar because of its low density relative to the magma.

The high $\mathrm{CaO} / \mathrm{Na}_{2} \mathrm{O}$ and high $\mathrm{MgO} / \mathrm{FeO}$ of the Site 236 magmas (Melson et al., 1977) indicates that they are high-temperature, primitive magmas that are capable of crystallizing the $\mathrm{An}_{85-88}$ plagioclase found in Site 707 magmas. The Site 236 glasses are similar in $\mathrm{MgO}$ and $\mathrm{TiO}_{2}$ contents to some rocks from Site 707 (Fig. 3A), but they cannot be the parents of the 
Table 12. Microprobe analyses of plagioclase phenocrysts, Site $\mathbf{7 1 5}$.

\begin{tabular}{|c|c|c|c|c|c|c|c|c|}
\hline $\begin{array}{l}\text { Hole no. } \\
\text { Unit no. } \\
\text { Core, section } \\
\text { Interval (cm) } \\
\text { Depth (mbsf) } \\
\text { Analysis no. }\end{array}$ & $\begin{array}{l}715 \mathrm{~A} \\
1 \\
23 \mathrm{R}-2 \\
26-28 \\
212.51 \\
1\end{array}$ & $\begin{array}{l}715 \mathrm{~A} \\
1 \\
23 \mathrm{R}-3 \\
44-46 \\
214.13 \\
1\end{array}$ & $\begin{array}{l}214.13 \\
2\end{array}$ & $\begin{array}{l}214.13 \\
3\end{array}$ & $\begin{array}{l}715 \mathrm{~A} \\
2 \\
25 \mathrm{R}-3 \\
25-27 \\
233.25 \\
1\end{array}$ & $\begin{array}{l}715 \mathrm{~A} \\
2 \\
25 \mathrm{R}-6 \\
37-38 \\
237.87 \\
1\end{array}$ & $\begin{array}{l}237.87 \\
2\end{array}$ & $\begin{array}{l}237.87 \\
3\end{array}$ \\
\hline $\begin{array}{l}\mathrm{SiO}_{2} \\
\mathrm{Al}_{2} \mathrm{O}_{3} \\
\mathrm{FeO} \\
\mathrm{CaO} \\
\mathrm{Na}_{2} \mathrm{O} \\
\mathrm{K}_{2} \mathrm{O}\end{array}$ & $\begin{array}{r}54.24 \\
27.75 \\
1.03 \\
11.20 \\
4.72 \\
0.27\end{array}$ & $\begin{array}{r}51.14 \\
30.29 \\
0.65 \\
14.28 \\
3.69 \\
0.13\end{array}$ & $\begin{array}{r}51.88 \\
29.71 \\
0.93 \\
13.54 \\
4.11 \\
0.17\end{array}$ & $\begin{array}{r}49.93 \\
31.41 \\
0.58 \\
15.13 \\
3.28 \\
0.11\end{array}$ & $\begin{array}{r}52.81 \\
30.06 \\
0.82 \\
12.37 \\
4.19 \\
0.17\end{array}$ & $\begin{array}{r}49.41 \\
32.01 \\
0.78 \\
14.97 \\
2.84 \\
0.10\end{array}$ & $\begin{array}{r}53.25 \\
28.21 \\
0.91 \\
11.93 \\
4.15 \\
0.25\end{array}$ & $\begin{array}{r}51.66 \\
30.01 \\
0.92 \\
13.80 \\
3.67 \\
0.13\end{array}$ \\
\hline Total & 99.21 & 100.17 & 100.34 & 100.44 & 100.43 & 100.11 & 98.70 & 100.19 \\
\hline $\begin{array}{l}\text { An } \\
\text { Notes }\end{array}$ & $\begin{array}{c}55.9 \\
\mathrm{~m}\end{array}$ & $\begin{array}{c}67.7 \\
\mathrm{c}\end{array}$ & $\begin{array}{r}64 \\
r\end{array}$ & $\begin{array}{c}71.4 \\
\mathrm{c}\end{array}$ & $\begin{array}{c}61.4 \\
\mathrm{~m}\end{array}$ & $\begin{array}{c}74.0 \\
\text { c }\end{array}$ & $\begin{array}{c}60.5 \\
\mathrm{r}\end{array}$ & $\begin{array}{c}67.0 \\
\mathrm{~m}\end{array}$ \\
\hline
\end{tabular}

\begin{tabular}{|c|c|c|c|c|c|c|c|c|}
\hline $\begin{array}{l}\text { Hole no. } \\
\text { Unit no. } \\
\text { Core, section } \\
\text { Interval (cm) } \\
\text { Depth (mbsf) } \\
\text { Analysis no. }\end{array}$ & $\begin{array}{l}715 \mathrm{~A} \\
3 \\
29 \mathrm{R}-1 \\
1-2 \\
267.71 \\
1\end{array}$ & 2 & $\begin{array}{l}715 \mathrm{~A} \\
3 \\
29 \mathrm{R}-1 \\
116-118 \\
268.86 \\
1\end{array}$ & $\begin{array}{l}715 \mathrm{~A} \\
3 \\
30 \mathrm{R}-3 \\
40-41 \\
274.10 \\
1\end{array}$ & 2 & 3 & 4 & $\begin{array}{l}715 \mathrm{~A} \\
3 \\
31 \mathrm{R}-2 \\
94-95 \\
280.64 \\
1\end{array}$ \\
\hline $\begin{array}{l}\mathrm{SiO}_{2} \\
\mathrm{Al}_{2} \mathrm{O}_{3} \\
\mathrm{FeO} \\
\mathrm{CaO} \\
\mathrm{Na}_{2} \mathrm{O} \\
\mathrm{K}_{2} \mathrm{O}\end{array}$ & $\begin{array}{r}49.33 \\
29.97 \\
0.72 \\
13.80 \\
3.96 \\
0.14\end{array}$ & $\begin{array}{r}48.24 \\
30.82 \\
0.64 \\
16.32 \\
2.45 \\
0.09\end{array}$ & $\begin{array}{r}58.39 \\
25.13 \\
0.65 \\
8.97 \\
6.90 \\
0.41\end{array}$ & $\begin{array}{r}47.46 \\
31.11 \\
0.55 \\
15.29 \\
2.75 \\
0.12\end{array}$ & $\begin{array}{r}48.81 \\
30.61 \\
0.59 \\
14.41 \\
3.28 \\
0.16\end{array}$ & $\begin{array}{r}53.67 \\
29.19 \\
0.85 \\
12.66 \\
4.45 \\
0.22\end{array}$ & $\begin{array}{r}51.05 \\
29.80 \\
0.69 \\
14.20 \\
4.00 \\
0.15\end{array}$ & $\begin{array}{r}58.15 \\
24.55 \\
0.91 \\
7.26 \\
6.69 \\
0.56\end{array}$ \\
\hline Total & 97.92 & 98.57 & 100.46 & 97.28 & 97.86 & 101.03 & 99.89 & 98.12 \\
\hline $\begin{array}{l}\text { An } \\
\text { Notes }\end{array}$ & $\begin{array}{c}65.3 \\
c\end{array}$ & $\begin{array}{c}78.3 \\
\mathrm{r}\end{array}$ & $\begin{array}{c}40.9 \\
r\end{array}$ & $\begin{array}{r}75 \\
\mathrm{c}\end{array}$ & $\begin{array}{c}70.2 \\
\mathrm{r}\end{array}$ & $\begin{array}{c}60.4 \\
\mathrm{r}\end{array}$ & $\begin{array}{c}65.8 \\
\mathrm{c}\end{array}$ & $\begin{array}{c}36.3 \\
\mathrm{~m}\end{array}$ \\
\hline
\end{tabular}

Notes: $\mathrm{c}=$ core, $\mathrm{r}=\mathrm{rim}$, and $\mathrm{m}=$ microphenocryst.

Site 707 magmas because of their high silica contents and low total alkalis (Fig. 3B) relative to the Site 707 basalts. Site 236 basalts are distinct from those of Site 707 and represent magmas produced by different melting conditions in the mantle, by melting of a distinct mantle composition, or by a different set of magmatic processes (magma chamber dynamics and assimilation). If magmas like those at Site $\mathbf{2 3 6}$ were involved in the generation of Site 707 magmas, then none of these magmas erupted at Site 707 and the only evidence that they could have existed is the high-An plagioclase that could have passed through the magma chamber without being assimilated.

The pyroxene compositions of chemical units 2 and 3 have a bimodal distribution in Mg\#, but in units 1 and 4 there are not enough analyses to demonstrate this. The majority of analyses from each flow have $\mathrm{Mg \# s}$ close to the equilibrium values given in Table 15. (The range of $\mathrm{Mg} \#$ values in Figure 8 is caused in part by the calculation of ferrous iron in the sample, which is sensitive to the accuracy of the $\mathrm{SiO}_{2}$ determination.)

Some augites in chemical unit 3 have the lowest $\mathrm{MgO}$ content (Mg\# 74) of augites from all four units, which may be caused by the re-equilibration of the pyroxenes as the unit cooled, as was also suggested by the low anorthite content of the plagioclase. The augite phenocrysts with the highest $\mathrm{Mg} \#$ are found near the top and bottom of this thick unit. These phenocrysts also have a high $\mathrm{Cr}_{2} \mathrm{O}_{3}$ content $(0.3-0.5 \mathrm{wt} \%$ ), implying that they crystallized from a magma rich in chromium. The decrease in $\mathrm{Cr}_{2} \mathrm{O}_{3}$ and $\mathrm{Mg \#}$ is the normal chemical change during cooling of augite in a magma and indicates that the augites in the center of the flow re-equilibrated as the unit cooled. Elevated concentrations of $\mathrm{Al}_{2} \mathrm{O}_{3}$ and $\mathrm{Na}_{2} \mathrm{O}$ in pyroxenes are often considered an indication of high-pressure crystallization of pyroxene (Thompson, 1975). The $\mathrm{Na}_{2} \mathrm{O}$ and $\mathrm{Al}_{2} \mathrm{O}_{3}$ concentrations in the high-
$\mathrm{Cr}_{2} \mathrm{O}_{3}$, high-MgO augite cores, however, are not different from the rims, which implies that the high-temperature cores of the augites crystallized close to the same pressure as the rims. The high-MgO augite cores may also represent xenocrysts from a more primitive magma that was mixed with the host magma, or they could originate from gabbroic cumulates from margins of the magma chamber that were incorporated before the eruption of this flow.

The trace element chemistry of basalts from the three Leg 24 sites in the old oceanic crust of the western Indian Ocean (Sites 235,236 , and 238) and present-day Indian Ocean Ridge basalts have unusually low $\mathrm{Ba}, \mathrm{Ti}$, and $\mathrm{Zr}$ abundances (Engel et al., 1974; Price et al., 1986) compared with lavas from the hotspot track (Duncan, Backman, et al., 1989) and compared with other ocean ridge basalts (Engel et al., 1974). Of the Réunion hotspot track basalts, however, those from chemical units 1 and 2 of Site 707 have the lowest abundances of these three elements (Duncan, Backman, et al., 1989), which implies that similar degrees of melting of the same mantle source accounts for the generation of the magmas at Sites 707 and 236.

The ratios of trace elements (e.g., $\mathrm{BaO} / \mathrm{TiO}_{2}$ ) from the older oceanic crust (Sites 235, 236, and 238) are the same as the present-day Indian Ocean Ridge basalts (Price et al., 1986) and are also the same as those for Site 707; but they are distinctly different from Sites 706, 713, and 715 and Réunion and Mauritius islands, which implies that the old and young ocean-floor basalts had the same mantle source as Site 707 .

\section{Site 713}

As in the previous two sites, there appears to be several populations of plagioclase compositions within each chemical unit (Fig. 9). The calculated equilibrium plagioclase content for each 
Table 13. Microprobe analyses of clinopyroxenes, Site 715 .

\begin{tabular}{|c|c|c|c|c|c|c|c|c|c|c|c|}
\hline $\begin{array}{l}\text { Hole no. } \\
\text { Unit no. } \\
\text { Core, section } \\
\text { Interval (cm) } \\
\text { Depth (mbsf) } \\
\text { Analysis no. }\end{array}$ & $\begin{array}{l}715 \mathrm{~A} \\
1 \\
23 \mathrm{R}-2 \\
26-28 \\
212.51 \\
1\end{array}$ & $\begin{array}{l}715 \mathrm{~A} \\
1 \\
23 \mathrm{R}-3 \\
44-46 \\
214.13 \\
1\end{array}$ & 2 & 3 & 4 & $\begin{array}{l}715 \mathrm{~A} \\
2 \\
25 \mathrm{R}-3 \\
25-27 \\
233.25 \\
1\end{array}$ & 2 & 3 & 4 & $\begin{array}{l}715 \mathrm{~A} \\
1 \\
25 \mathrm{R}-6 \\
37-38 \\
237.87 \\
1\end{array}$ & 2 \\
\hline $\mathrm{SiO}_{2}$ & 48.17 & 51.62 & 51.04 & 51.85 & 50.01 & 51.37 & 50.96 & 49.75 & 51.47 & 51.28 & 52.17 \\
\hline $\mathrm{TiO}_{2}$ & 1.17 & 0.40 & 0.68 & 0.59 & 0.87 & 0.53 & 0.77 & 1.00 & 0.63 & 0.98 & 0.56 \\
\hline $\mathrm{Al}_{2} \mathrm{O}_{3}$ & 4.40 & 1.79 & 2.01 & 2.11 & 2.47 & 3.92 & 1.80 & 2.22 & 2.41 & 2.27 & 2.70 \\
\hline $\mathrm{FeO}$ & 11.08 & 9.48 & 10.00 & 9.56 & 11.48 & 6.56 & 13.50 & 19.42 & 9.05 & 12.25 & 7.24 \\
\hline $\mathrm{MnO}$ & 0.25 & 0.21 & 0.24 & 0.23 & 0.26 & 0.18 & 0.38 & 0.53 & 0.23 & 0.40 & 0.15 \\
\hline $\mathrm{MgO}$ & 14.63 & 14.93 & 15.27 & 15.04 & 14.45 & 15.82 & 15.24 & 11.05 & 15.32 & 15.98 & 16.39 \\
\hline $\mathrm{CaO}$ & 18.01 & 21.09 & 19.17 & 20.61 & 18.29 & 20.67 & 16.37 & 13.85 & 19.95 & 16.91 & 21.00 \\
\hline $\mathrm{Na}_{2} \mathrm{O}$ & 0.34 & 0.26 & 0.21 & 0.25 & 0.23 & 0.22 & 0.23 & 0.25 & 0.27 & 0.28 & 0.25 \\
\hline $\mathrm{Cr}_{2} \mathrm{O}_{3}$ & 0.05 & 0.05 & 0.26 & 0.10 & 0.08 & 0.92 & ${ }^{\mathrm{a}} 0.04$ & ${ }^{\mathrm{a}} 0.04$ & 0.06 & ${ }^{\mathrm{a}} 0.04$ & 0.24 \\
\hline Total & 98.11 & 99.82 & 98.88 & 100.34 & 98.13 & 100.19 & 99.30 & 98.11 & 99.39 & 100.39 & 100.71 \\
\hline Notes & c & c & $r$ & c & $r$ & c & $r$ & $r$ & c & $r$ & c \\
\hline $\mathrm{Mg \#}$ & 70 & 79 & 76 & 77 & 72 & 82 & 69 & 50 & 78 & 73 & 84 \\
\hline
\end{tabular}

\begin{tabular}{|c|c|c|c|c|c|c|c|c|c|}
\hline $\begin{array}{l}\text { Hole no. } \\
\text { Unit no. } \\
\text { Core, section } \\
\text { Interval (cm) } \\
\text { Depth (mbsf) } \\
\text { Analysis no. }\end{array}$ & $\begin{array}{l}715 \mathrm{~A} \\
3 \\
29 \mathrm{R}-1 \\
1-2 \\
267.71 \\
1\end{array}$ & 2 & $\begin{array}{l}715 \mathrm{~A} \\
3 \\
29 \mathrm{R}-1 \\
116-118 \\
268.86 \\
1\end{array}$ & 2 & $\begin{array}{l}715 \mathrm{~A} \\
3 \\
30 \mathrm{R}-3 \\
40-41 \\
274.10 \\
1\end{array}$ & 2 & $\begin{array}{l}715 \mathrm{~A} \\
3 \\
31 \mathrm{R}-2 \\
94-95 \\
280.64 \\
1\end{array}$ & 2 & 3 \\
\hline $\mathrm{SiO}_{2}$ & 52.02 & 51.56 & 49.01 & 49.14 & 51.81 & 50.59 & 50.52 & 50.26 & 49.47 \\
\hline $\mathrm{TiO}_{2}$ & 0.77 & 0.71 & 1.02 & 1.32 & 0.64 & 0.89 & 2.00 & 1.50 & 1.74 \\
\hline $\mathrm{Al}_{2} \mathrm{O}_{3}$ & 3.01 & 3.19 & 2.55 & 1.96 & 1.35 & 0.78 & 1.14 & 3.55 & 2.87 \\
\hline $\mathrm{FeO}$ & 7.56 & 7.84 & 11.24 & 17.86 & 6.55 & 13.61 & 17.24 & 9.68 & 12.89 \\
\hline $\mathrm{MnO}$ & 0.16 & 0.19 & 0.23 & 0.37 & 0.15 & 0.43 & 0.56 & 0.22 & 0.30 \\
\hline $\mathrm{MgO}$ & 14.97 & 14.82 & 14.91 & 9.56 & 16.63 & 15.07 & 11.41 & 14.62 & 12.58 \\
\hline $\mathrm{CaO}$ & 20.72 & 20.04 & 18.29 & 19.04 & 20.63 & 16.57 & 16.19 & 19.93 & 19.76 \\
\hline $\mathrm{Na}_{2} \mathrm{O}$ & 0.21 & 0.17 & 0.35 & 0.16 & 0.27 & 0.31 & 0.29 & 0.32 & 0.30 \\
\hline $\mathrm{Cr}_{2} \mathrm{O}_{3}$ & 0.51 & 0.66 & 0.12 & ${ }^{a} 0.04$ & 0.73 & ${ }^{\mathrm{a}} 0.04$ & ${ }^{\mathrm{a}} 0.04$ & 0.27 & ${ }^{\mathrm{a}} 0.04$ \\
\hline Total & 99.92 & 99.17 & 97.72 & 99.45 & 98.76 & 98.30 & 99.39 & 100.34 & 99.95 \\
\hline Notes & $r$ & $\mathrm{~m}$ & $\mathrm{c}$ & $\mathrm{r}$ & c & $r$ & r & c & r \\
\hline $\mathrm{Mg \#}$ & 78 & 77 & 75 & 49 & 83 & 67 & 54 & 76 & 66 \\
\hline
\end{tabular}

Notes: $\mathrm{c}=$ core, $\mathrm{r}=$ rim, and $\mathrm{m}=$ microphenocryst.

${ }^{\mathrm{a}}$ Minimum detection limit for $\mathrm{Cr}_{2} \mathrm{O}_{3}$ is $0.04 \mathrm{wt} \%$.

Table 14. Microprobe analyses of olivines, Site 715.

\begin{tabular}{|c|c|c|c|c|c|c|c|c|}
\hline $\begin{array}{l}\text { Hole no. } \\
\text { Unit no. } \\
\text { Core, section } \\
\text { Interval (cm) } \\
\text { Depth (mbsf) } \\
\text { Analysis no. }\end{array}$ & $\begin{array}{l}715 \mathrm{~A} \\
3 \\
30 \mathrm{R}-3 \\
40-41 \\
274.10 \\
1\end{array}$ & 2 & 3 & 4 & 5 & 6 & 7 & 8 \\
\hline $\mathrm{SiO}_{2}$ & 38.43 & 38.58 & 38.49 & 36.86 & 38.58 & 37.71 & 37.91 & 37.50 \\
\hline $\mathrm{FeO}$ & 17.94 & 21.35 & 19.17 & 24.98 & 19.27 & 22.11 & 20.53 & 23.72 \\
\hline $\mathrm{MnO}$ & 0.29 & 0.34 & 0.31 & 0.39 & 0.27 & 0.29 & 0.32 & 0.38 \\
\hline $\mathrm{MgO}$ & 42.29 & 39.18 & 41.09 & 36.45 & 41.07 & 38.60 & 39.66 & 37.64 \\
\hline $\mathrm{NiO}$ & 0.25 & 0.20 & 0.19 & 0.20 & 0.21 & 0.16 & 0.13 & 0.16 \\
\hline Total & 99.19 & 99.65 & 99.24 & 98.89 & 99.41 & 98.87 & 98.56 & 99.40 \\
\hline FO & 80.8 & 76.6 & 79.3 & 72.2 & 79.2 & 75.7 & 77.5 & 73.9 \\
\hline Notes & c & $r$ & c & $\mathrm{r}$ & c & r & c & $\mathrm{r}$ \\
\hline
\end{tabular}

Notes: $\mathrm{c}=$ core, $\mathrm{r}=\mathrm{rim}$, and $\mathrm{m}=$ microphenocryst.

of the units (Table 15) is within 5 mole $\%$ of $\mathrm{An}_{70}$, which corresponds to the rims of the phenocrysts and the groundmass plagioclase, but plagioclase of $\mathrm{An}_{80-87}$ is found in the cores of all of the large phenocrysts or xenocrysts.

The plagioclase analyses from the volcanic turbidite that separates units 2 and 3 are clearly more evolved (lower temperature) than those above or below it, and they must be derived from an evolved lava that did not extend to the drill site. The glass in this

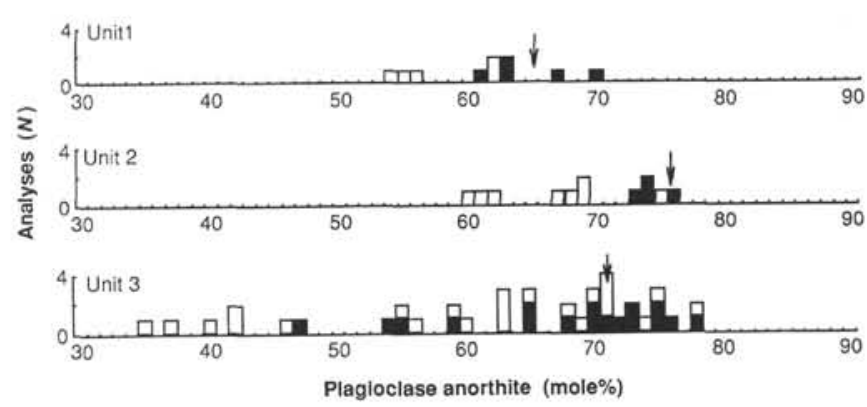

Figure 11. Histogram of anorthite content of plagioclase from the three chemical units of Site 715. This is the one site that does not have the high-anorthite plagioclase.

same turbidite (115-713A-17R-2, 41-44 cm; Table 10) had high $\mathrm{Na}_{2} \mathrm{O}$ and low $\mathrm{CaO}$ and could have been the host magma for these feldspars.

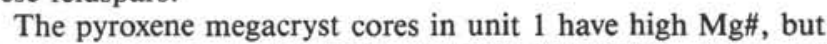
they do not appear to be distinguished by high $\mathrm{TiO}_{2}, \mathrm{Cr}_{2} \mathrm{O}_{3}$, or $\mathrm{Al}_{2} \mathrm{O}_{3}$. Unlike the plagioclase megacrysts, the cores of the augites seem to have crystallized from a magma that was chemically similar to the host magma except that it had a higher $\mathrm{MgO}$ content and, therefore, a higher temperature. Unit 3 contains 


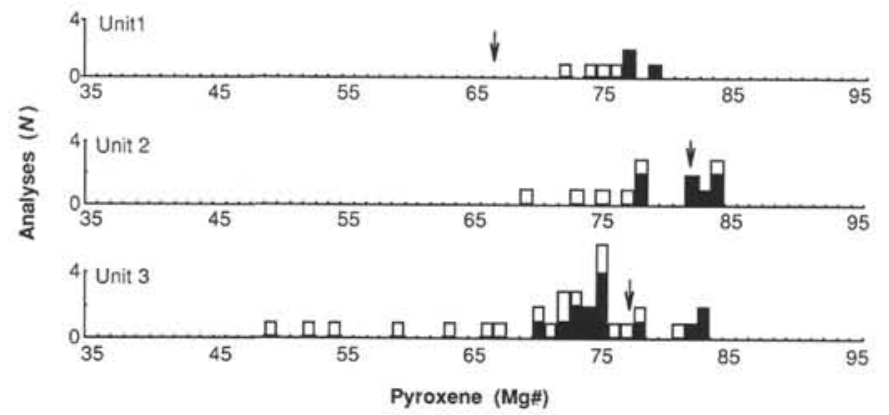

Figure 12. Histogram of magnesium-augite $\mathrm{Mg \#}$ of phenocrysts cores and rims in groundmass in Site 715 basalts.

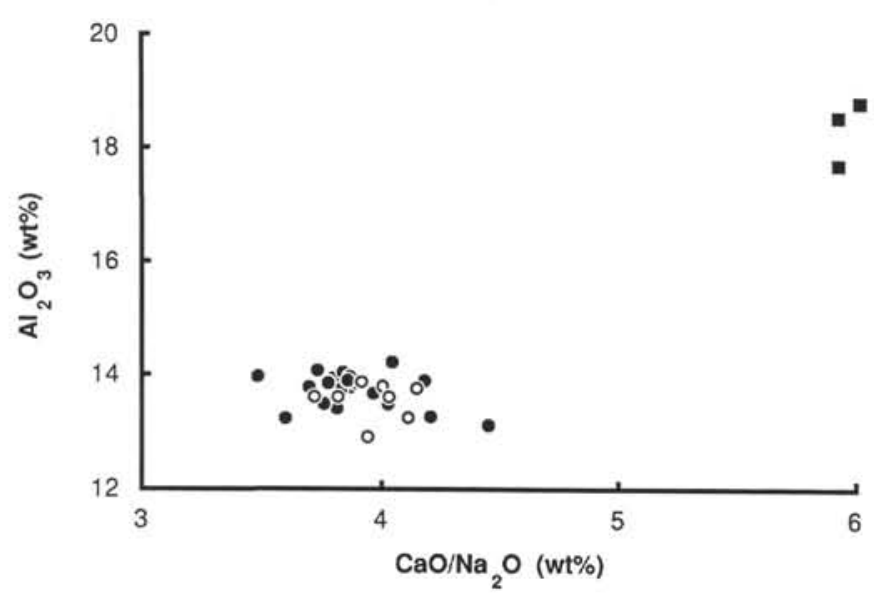

Figure 13. $\mathrm{CaO} / \mathrm{Na}_{2} \mathrm{O}$ vs. $\mathrm{Al}_{2} \mathrm{O}_{3}$ for chemical units from Site 706 . Chemical unit 1 , filled circles; chemical unit 2 , open circles; and chemical unit 3, squares.

Table 15. Equilibrium mineralogy of chemical units.

\begin{tabular}{|c|c|c|c|c|c|c|c|c|c|c|}
\hline \multirow[b]{2}{*}{ Site } & \multirow[b]{2}{*}{ Unit } & \multicolumn{2}{|c|}{ Olivine } & \multicolumn{2}{|c|}{ Plagioclase } & \multicolumn{2}{|c|}{ Augite } & \multirow[b]{2}{*}{ En } & \multirow[b]{2}{*}{ Fs } & \multirow[b]{2}{*}{ Mg\# } \\
\hline & & $\mathrm{T}^{\circ} \mathrm{C}$ & Forsterite & $\mathrm{T}^{\circ} \mathrm{C}$ & Anorthite & $\mathrm{T}^{\circ} \mathrm{C}$ & Wo & & & \\
\hline 706 & 1 & a- & - & 1143 & 61 & 1130 & 39 & 44 & 17 & 72 \\
\hline 706 & 2 & a- & - & 1143 & 62 & 1133 & 39 & 45 & 16 & 74 \\
\hline 706 & 3 & 1152 & 78 & 1246 & 77 & 1167 & 41 & 48 & 10 & 83 \\
\hline 707 & 1 & 1262 & 86 & 1184 & 68 & 1148 & 35 & 47 & 18 & 85 \\
\hline 707 & 2 & 1194 & 85 & 1212 & 76 & 1185 & 40 & 50 & 10 & 83 \\
\hline 707 & 3 & 1167 & 79 & 1192 & 71 & 1163 & 38 & 48 & 14 & 77 \\
\hline 707 & 4 & 1168 & 79 & 1178 & 67 & 1159 & 38 & 48 & 14 & 77 \\
\hline 713 & 1 & 1172 & 82 & 1194 & 71 & 1172 & 40 & 49 & 11 & 82 \\
\hline 713 & 2 & a- & - & 1170 & 68 & 1157 & 42 & 47 & 13 & 78 \\
\hline 713 & 3 & 1174 & 82 & 1210 & 74 & 1183 & 41 & 50 & 9 & 85 \\
\hline 715 & 1 & 1142 & 72 & 1167 & 65 & 1126 & 34 & 44 & $b_{22}$ & 66 \\
\hline 715 & 2 & 1259 & 89 & 1195 & 76 & 1175 & 39 & 50 & 11 & 82 \\
\hline 715 & 3 & 1229 & 87 & 1187 & 71 & 1155 & 37 & 47 & 15 & 76 \\
\hline
\end{tabular}

Note: Mineral compositions and crystallization temperatures by methods of Nielsen (1988). a Olivine does not appear on the liquidus even after $60 \%$ crystallization.

${ }^{b}$ Low calcium pyroxene (Wo 4 En $69 \mathrm{Fs} 27$ ) appears at $1129^{\circ} \mathrm{C}$.

crystallized augite with uniformly high $\mathrm{Mg \# s}$ that are close to values expected for the composition of the magma (Table 15).

Olivine is preserved in fresh glass in chemical unit 3 (below the ash-chalk layer) and is virtually unzoned; all but one of the analyses fall within the range of $\mathrm{FO}_{81.7-82.5}$. This absence of zoning indicates that the olivine grew isothermally and was then quenched rapidly. The presence of many thin lithologic units with glassy contacts in the lower part of the hole indicates that

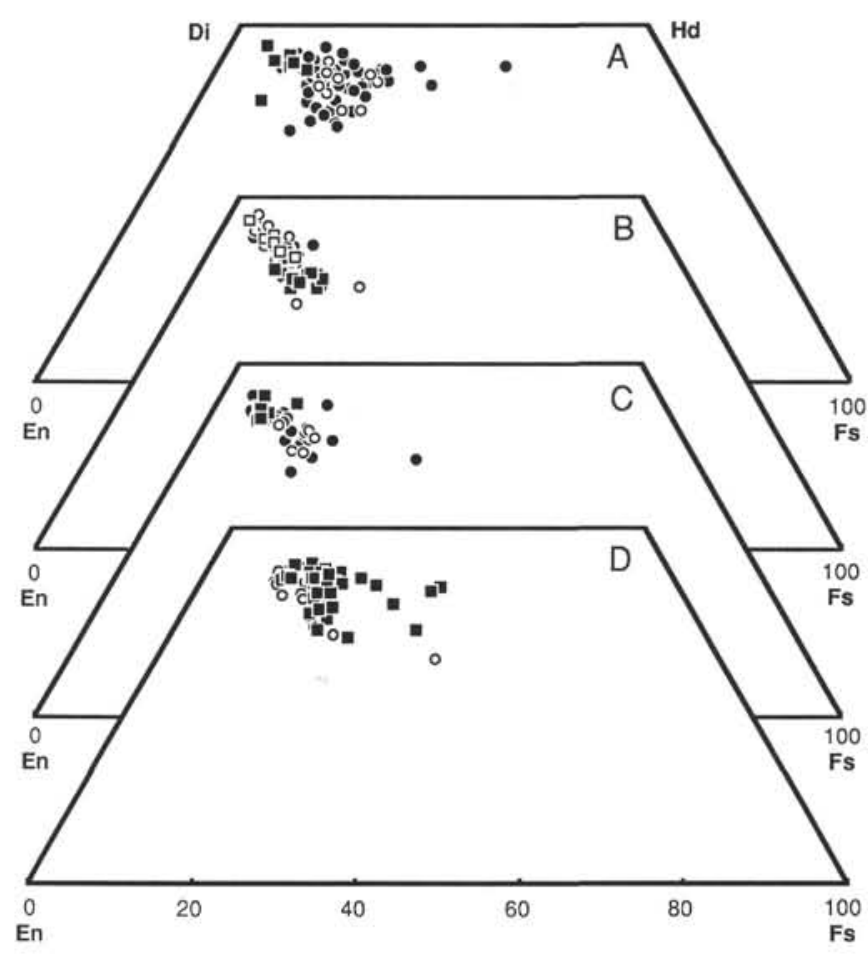

Figure 14. Pyroxene quadrilateral diagrams for all pyroxene analyses from Leg 115. A. Site 706: chemical unit 1, solid circles; chemical unit 2, open circles; chemical unit 3, solid squares. B. Site 707. Symbols for chemical units 1, 2, and 3 are the same as for Site 706; chemical unit 4, open squares. C. Site 713. Symbols are the same as for Site 706. D. Site 715. Symbols are the same as for Site 706 .

these lavas were submarine and could have been quenched quickly, thus preserving the original mineralogy. The olivines found in these flows (Table 11) have compositions that agree with the calculated equilibrium olivine compositions (Table 15), and there do not appear to be any high-Fo olivines that correspond to the primitive plagioclase $\left(\mathrm{An}_{86-87}\right)$. This could result from the fact that olivine re-equilibrates with basaltic magma much more quickly than does plagioclase, so the olivine may have had time to equilibrate at lower temperatures in the magma chamber and the plagioclase did not. Alternatively, the magma that produced the $\mathrm{An}_{86-87}$ plagioclase could have been free of olivine or contained olivine that was $\mathrm{Fo}_{82}$.

In chemical unit 3 , however, augite is found primarily as megacrysts with high $\mathrm{Mg} \#$ (assuming stoichiometry and recalculating total iron to $\mathrm{Fe}^{2+}$ and $\mathrm{Fe}^{3+}$ ). It is possible that the augite represents the remnants of the high-temperature parent magma to unit 3. Some of the augite cores have a high $\mathrm{Cr}_{2} \mathrm{O}_{3}$ content, which also implies that they crystallized from a more primitive magma. The oxide minerals at Site 713 are found only in the groundmass and are typical of the magnetites that are found in the other sites on Leg 115.

\section{Site 715}

The feldspars at Site 715 do not have the characteristic bimodal character observed at the other sites along the Réunion hotspot track (Fig. 11), and in all three units the calculated equilibrium composition of the plagioclase (arrows) are within 5 mole $\%$ anorthite of the most abundant phenocryst core compositions. Chemical unit 3 is made up of many flows and has a wide range of plagioclase compositions (Fig. 11), and the feldspar is normally as well as reversely zoned. The phenocryst cores range 
from $\mathrm{An}_{47-78}$, and the rims cover much of the same range. The microphenocrysts have lower An contents $\left(\mathrm{An}_{35-45}\right)$ and probably represent late-stage crystallization.

Using the classification of Papike et al. (1974), the pyroxenes are $\mathrm{Mg}$-augites throughout the section and have a similar distribution of $\mathrm{Mg} \#$ as the An contents of the feldspars. There is a hint of bimodal $\mathrm{Mg} \#$ in chemical unit 2, and the wide scatter in $\mathrm{Mg} \#$ in chemical unit 3 is much like the scatter in the An content of plagioclase from the same unit. The $\mathrm{Mg \# s}$ agree fairly well with the calculated equilibrium augites (Table 15), except in unit 1 where pigeonite is predicted to crystallize before augite and the augite has an $\mathrm{Mg \#}$ of 66 . No pigeonite was found in this unit, and the predicted augite $\mathrm{Mg \#}$ is well below that observed in unit 1.

The similarity of the calculated crystallization temperatures of the four phases (olivine, plagioclase, and two pyroxenes) in unit 1 suggests that this magma is close to four-phase saturation. The presence of augite with considerably higher $\mathrm{Mg \#}$ than predicted with the computer model implies that the augites are xenocrysts. This upper unit is also one of the most alkaline from Leg 115 (Fig. 3B).

\section{Mineralogical Variation along the Réunion Hotspot Track}

In the Deccan, Réunion, and Mauritius lavas, olivine is the dominant phenocryst (Beane et al., 1986; Upton and Wadsworth, 1972; Baxter, 1976), whereas the lavas from intervening locations (Sites 706, 707, and 713) are primarily dominated by plagioclase phenocrysts. The exception to this is Site 715 , in which olivine is usually more abundant than plagioclase or augite. The reason for the abundance of plagioclase and augite at Sites 706, 707, and 713 is not clear, and a number of alternatives are possible.

1. The lavas at Sites 706,707 , and 713 are volcano-capping, evolved lavas, similar to the Differentiated Series lavas of Réunion (Upton and Wadsworth, 1972), and are not typical, therefore, of the remainder of the volcanic products from each site.

2. The primary magmas that fed the magma chambers at Sites 706,707 , and 713 may have been a mixture of an olivinerich magma and a more evolved magma similar to Indian Ocean mid-ocean ridge basalts (MORB).

3. The recharge rate of the magma chambers for these three sites may have been low compared with Deccan, Réunion, Mauritius, and Site 715 .

\section{Comparison of Réunion Differentiated Series and Sites 706, 707 , and 713}

We will only know if the lavas from Sites 706,707 , and 713 are typical of the volcanoes from which they came when additional samples are obtained. We may speculate, however, that the lavas represent a cap of differentiated basalts like those that are found on Réunion. Piton des Neiges on Réunion Island, for example, is covered with feldspar-phyric lavas known as the "Differentiated Series" (Upton and Wadsworth, 1965). The Differentiated Series, however, is dominated by lavas with less than $5.0 \mathrm{wt} \% \mathrm{MgO} ; 81$ out of 94 published and unpublished analyses of Differentiated Series lavas have less than $5.25 \% \mathrm{MgO}$ (Fisk and Nielsen, 1989), but all of the units from Sites 706, 707 , and 713 have more than $5.25 \% \mathrm{MgO}$ (Fisk et al., 1989). It does not appear that the basalts collected at these three sites are plagiocläse-phyric simply because they are evolved caps of their individual volcanos.

\section{Magma Mixing}

Basalts at Sites 706, 707, and 713 were erupted on or close to a spreading ridge, and the chemistry of their basalts may be explained by the mixing of two magma types, one typical of the ocean islands and one typical of an ocean rift (Fisk et al., 1989). A mixed magma may stabilize plagioclase relative to olivine if the ocean-rift magmatic component has high $\mathrm{Al}_{2} \mathrm{O}_{3}$ and possibly high $\mathrm{SiO}_{2}, \mathrm{CaO} / \mathrm{Na}_{2} \mathrm{O}$, and $\mathrm{FeO} / \mathrm{MgO}$, similar to the glasses found in the Paleocene ocean-floor lavas at DSDP Site 236 (Melson et al., 1977).

The bimodal distribution of plagioclase phenocryst compositions in Sites 706, 707, and 713 (Figs. 5, 7, and 9) may also provide evidence of mixing. The high-anorthite content plagioclase could not have crystallized from the host magma but was probably derived from a primitive magma that was not sampled at any of the sites. It can be argued that these high-anorthite plagioclase "xenocrysts" resulted from the random incorporation of previously crystallized plagioclase into an erupting basalt. Preserving and erupting the xenocrysts but not the primitive magmas from which they crystallized requires that certain special conditions be met. The high-temperature plagioclase phenocrysts must be separated from their parent magma and the co-crystallizing olivine and they must be stored (possibly, as a crystal mush) at the top or sides of a magma chamber so that they can be easily disrupted and incorporated into an erupting magma.

Plagioclase gravitationally separates from olivine because of their different densities (2.7 for $\mathrm{An}_{88}$ and 3.3 for $\mathrm{Fo}_{85}$ ) relative to mafic silicates. Plagioclase would sink slowly (less than $5 \mathrm{~cm}$ / $\mathrm{hr}$ ) or possibly float, depending on the composition of the host magma, whereas olivine would sink at more than $50 \mathrm{~cm} / \mathrm{hr}$ (Kushiro, 1980). The low density of the plagioclase may allow them to plate the walls and top of the magma chamber, making them easy to assimilate by an erupting magma.

The fact that the plagioclase chemistry exhibits a bimodal distribution complicates this explanation because a bimodal distribution requires that out of the continuum of plagioclase compositions that crystallize from a cooling magma, only a portion of them are reincorporated into the evolved magmas. For example, in chemical unit 1 of Site 707 (Fig. 7), the magma that produced the $\mathrm{An}_{86-88}$ xenocrysts did not also produce $\mathrm{An}_{75-85}$ plagioclase unless there was some mechanism for destroying or removing these intermediate composition plagioclase "xenocrysts."

The bimodal character of the plagioclase compositions could be produced if a primitive magma with high-anorthite plagioclase phenocrysts mixed with the pre-existing magma in the chamber and triggered an eruption at the same time. In this way no intermediate plagioclase compositions would ever be produced unless the volume of the primitive magma was greater than half of the magma chamber volume. Recharge volumes for the Réunion Island magma system, however, are thought to be about $3 \%-5 \%$ of the magma chamber volume (Fisk and Nielsen, 1989).

\section{Magma Chamber Dynamics}

A third explanation of the presence of the more evolved, augite-plagioclase basalts at Sites 706, 707, and 713 depends on the magma supply rate (recharge rate) and magma chamber volume. O'Hara (1977) developed a model of major and trace element chemical evolution of magmas that was dependent on the rate of magma recharge into the magma chamber, on the amount of crystallization within the magma chamber, on the amount of assimilation, and on the amount of magma erupted. This model can also be applied to the study of the mineralogy of the erupted basalts.

The order of silicate mineral crystallization with descending temperature of a tholeiite magma is almost always olivine, followed by plagioclase, followed by augite. In alkali basalts, again olivine is the first mineral to crystallize, but augite sometimes precedes plagioclase as the second most abundant mineral. Higher pressures will favor augite formation relative to plagioclase (Bender 
et al., 1978). In general, the more evolved, cooler magmas will have a low abundance of olivine and a high abundance of plagioclase and augite phenocrysts, and the high-temperature, primitive magmas will have a high proportion of olivine. A magma chamber that is maintained at a high temperature will, therefore, erupt more magmas that have abundant olivine. This will happen if the magma chamber is recharged frequently and the volume of the recharge is a large fraction of the volume of the magma chamber. The large volume and short interval for the eruption of the majority of the Deccan lavas indicates that these magma chambers were frequently recharged with large volumes of magma. Under these conditions, the erupted magmas are expected to contain abundant olivine, which proves to be the case (Beane et al., 1986).

If the less voluminous eruptions along the hotspot are the result of low recharge rate, then these magmas would be expected to be dominated by plagioclase and/or pyroxene, and this is the case for lavas from Sites 706, 707, and 713 but not for the islands of Réunion (Upton and Wadsworth, 1972) or Mauritius (Baxter, 1975, 1976) or for Site 715, which are all dominated by olivine phenocrysts. It is interesting that Sites 706, 707, and 713 not only have similar mineralogy but also have similar incompatible trace element abundance ratios (Fisk et al., 1989). This is also true of the lavas from Site 715, Réunion, and Mauritius, which form a group distinct from lavas at Sites 706, 707, and 713.

Réunion, Mauritius, and Site 715 are isolated volcanoes with a single magma supply (the hotspot). As such, they might be expected to have low magma supply rates relative to Sites 706,707 , and 713 , which are located near a mid-ocean rift and may have two magmatic sources: the ridge and the hotspot. The critical factor, however, is not the absolute supply rate but the supply rate relative to the magma chamber volume. If magma chambers at or near the rifts (Sites 706, 707, and 713) are large relative to those at Réunion, then even with a high magma supply rate the magmas could be more evolved than those found at Réunion and the mineralogy of magmas could be dominated by plagioclase.

\section{CONCLUSIONS}

Basalts collected from four drill sites in the western Indian Ocean along the Réunion hotspot track range in composition from tholeiites to alkali basalts similar to those found in the Deccan Traps and at Réunion and Mauritius islands. The dominant minerals in the basalts are plagioclase and augite, in contrast to the olivine-dominated lavas of Deccan and Réunion. Basalts of Site 715 are most like Réunion lavas in chemistry and mineralogy; this may be a result of the similar plate tectonic environment of volcanism at Réunion and Site 715. The other three drill sites $(706,707$, and 713$)$ appear to have bimodal distributions of plagioclase composition that could be the result of mixing of rift and hotspot magmas.

\section{ACKNOWLEDGMENTS}

Thanks to shipmate petrologists who worked on the core and thin section descriptions that are summarized here. Special thanks are due the technical crew who helped in all aspects of sample preparation and analyses, and especially to John Weisbruch for preparing the polished thin sections and Bettina Domeyer for her X-ray fluorescence analyses. We would also like to thank two incredibly patient reviewers, John Bender and Michael Perfit, for tackling an earlier draft of this paper and providing numerous constructive comments.

\section{REFERENCES}

Albee, A. L., and Ray, L., 1970. Correction factors for electron probe microanalysis of silicates, oxides, carbonates, phosphates and sulfides. Anal. Chem., 42:1408-1414.
Backman, J., Duncan, R. A., et al., 1988. Proc. ODP, Init. Repts., 115: College Station, TX (Ocean Drilling Program).

Baxter, A. N., 1972. Magmatic evolution of Mauritius, western Indian Ocean [Ph.D. thesis]. Univ. Edinburgh, Scotland, U.K.

1975. Petrology of the older series lavas from Mauritius, Indian Ocean. Geol. Soc. Am. Bull., 86:1449-1458.

1976. Geochemistry and petrogenesis of primitive alkali basalt from Mauritius, Indian Ocean. Geol. Soc. Am. Bull., 87:10281034.

Beane, J. E., Turner, C. A., Hooper, P. R., Subbarao, K. V., and Walsh, J. N., 1986. Stratigraphy, composition and form of the Deccan basalts, Western Ghats, India. Bull. Volcanol., 48:61-83.

Bence, A. E., and Albee, A. L., 1968. Empirical correction factors for electron microanalysis of silicates and oxides. J. Geol., 76:382-403.

Bender, J. F., Hodges, F. N, and Bence, A. E., 1978. Petrogenesis of basalts from the Project FAMOUS area: experimental study from 0 to 15 kbars. Earth Planet. Sci. Lett., 41:277-302.

Cox, K. G., and Hawkesworth, C. J., 1985. Geochemical stratigraphy of the Deccan Traps at Mahabaleshwar, Western Ghats, India, with implications for open-system magmatic processes. J. Petrol., 26:355377.

Dewey, C. W., and Lightfoot, P. C., 1986. Volcanological and tectonic control of stratigraphy and structure in the western Deccan Traps. Bull. Volcanol., 48:195-207.

Duncan, R. A., Backman, J., and Shipboard Scientific Party, 1989. Réunion hotspot activity through Tertiary time: initial results from the Ocean Drilling Program, Leg 115. J. Volcanol. Geotherm. Res., 36: 193-198.

Engel, C. C., Bingham, E., and Fisher, R. L., 1974. Trace element compositions of Leg 24 basalts and one diabase. In Fisher, R. L., Bence, E. T., et al., Init. Repts. DSDP, 24: Washington (U.S. Govt. Printing Office), 781-786.

Fisk, M. R., 1984. Depths and temperatures of mid-ocean-ridge magma chambers and the composition of their source magmas. In Gass, I. G., Lippard, S. J., and Shelton, A. W., Ophiolites and the Oceanic Lithosphere: London (Blackwell Scientific Publications), 17-23.

Fisk, M. R., Bence, A. E., and Schilling, J.-G., 1982. Major element chemistry of Galapagos Rift Zone magmas and their phenocrysts. Earth Planet. Sci. Lett., 61:171-189.

Fisk, M. R., Duncan, R. A., Baxter, A. N., Greenough, J. D., Hargraves, R. B., Tatsumi, Y., and Shipboard Scientific Party, 1989. Reunion hotspot magma chemistry over the past 65 m.y.: results from Leg 115 of the Ocean Drilling Program. Geology, 17:934-937.

Fisk, M. R., and Nielsen, R. L., 1989. Estimating the recharge rate and the interval between recharge events for the Réunion Island volcanic system. Eos, 70:1383-1384.

Fisk, M. R., Upton, B.G.J., Ford, C. E., and White, W. M., 1988. Geochemical and experimental study of the genesis of magmas of Réunion Island, Indian Ocean. J. Geophys. Res., 93:4933-4950.

Ford, C. E., Russell, D. G., Craven, J. A., and Fisk, M. R. 1983. Olivine-liquid equilibria: temperature, pressure and compositional dependence of the crystal/liquid cation partition coefficients for $\mathrm{Mg}$, $\mathrm{Fe} 2+, \mathrm{Ca}$, and Mn. J. Petrol., 24:256-265.

Kushiro, I., 1980. Viscosity, density, and structure of silicate melts at high pressures, and their petrologic applications. In Hargraves, R. B., Physics of Magmatic Processes: Princeton, NJ (Princeton Univ. Press).

Macdonald, G. A., and Katsura, T., 1964. Chemical composition of Hawaiian lavas. J. Petrol., 5:82-133.

Melson, G. W., Byerly, G. R., Nelen, J. A., O'Hearn, T., Wright, T. L. and Vallier, T., 1977. A catalog of the major element chemistry of abyssal volcanic glasses. Smithsonian Contrib. Earth Sci., 19:31-60.

Nielsen, R. L., 1988. A model for the simulation of combined major and trace element liquid lines of descent. Geochim. Cosmochim. Acta, 52:27-38.

O'Hara, M. J., 1977. Geochemical evolution during fractional crystallization of a periodically refilled magma chamber. Nature, 266:503507.

Papike, J. J., Cameron, K. L., and Baldwin, K., 1974. Amphiboles and pyroxenes: characterization of other than quadrilateral components and estimates of ferric iron from microprobe data. Geol. Soc. Am., Abstr. Prog., 6:1053-1054.

Perfit, M. R., and Fornari, D. J., 1983. Geochemical studies of abyssal lavas recovered by DSRV Alvin from eastern Galapagos Rift, Inca Transform, and Ecuador Rift 2. Phase chemistry and crystallization history. J. Geophys. Res., 88:10,530-10,550. 
Price, R. C., Kennedy, A. K., Riggs-Sneeringer, M., and Frey, F. A., 1986. Geochemistry of basalts from the Indian Ocean triple junction: implications for generation and evolution of Indian Ocean ridge basalts. Earth Planet. Sci. Lett., 78:379-396.

Roeder, P. L., and Emslie, R. F., 1970. Olivine-melt equilibrium. Contrib. Mineral. Petrol., 19:75-289.

Thompson, R. N., 1975. Primary basalts and magma genesis. Contrib. Mineral. Petrol., 52:213-232.
Upton, B.G.J., and Wadsworth, W. J., 1965. Geology of Réunion Island, Indian Ocean. Nature, 207:51-154.

1972. Aspects of magmatic evolution of Réunion Island. Phil. Trans. R. Soc. London, Ser. A, 271:105-130.

Date of initial receipt: 13 June 1989

Date of acceptance: 8 January 1990

Ms 115B-122

Appendix. Thin sections probed on samples from Leg 115.

\begin{tabular}{|c|c|c|c|}
\hline $\begin{array}{l}\text { Core, section, } \\
\text { interval }(\mathrm{cm})\end{array}$ & $\begin{array}{l}\text { Phases } \\
\text { analyzed }\end{array}$ & $\begin{array}{l}\text { Lithologic } \\
\text { unit (flow) }\end{array}$ & $\begin{array}{c}\text { Chemical } \\
\text { unit }\end{array}$ \\
\hline $115-706 \mathrm{~A}-6 \mathrm{H}-4,20-24$ & PI, Px & 1 & 1 \\
\hline $115-706 \mathrm{~B}-7 \mathrm{X}-\mathrm{CC}, 17-20$ & $\mathrm{Pl}, \mathrm{Px}, \mathrm{Gl}$ & - & - \\
\hline 115-706B-7X-CC, $20-27$ & $\mathrm{Pl}, \mathrm{Px}, \mathrm{Gl}$ & 1 & 1 \\
\hline $115-706 \mathrm{C}-2 \mathrm{R}-1,76-80$ & $\mathrm{Pl}, \mathrm{Px}, \mathrm{Gl}$ & 1 & 1 \\
\hline $115-706 C-2 R-2,2-4$ & $\mathrm{Pl}, \mathrm{Px}, \mathrm{Gl}$ & 3 & 1 \\
\hline $115-706 \mathrm{C}-2 \mathrm{R}-2,115-118$ & $\mathrm{PI}, \mathrm{Px}$ & 8 & 1 \\
\hline $115-706 C-5 R-1,83-85$ & $\mathrm{Pl}, \mathrm{Px}$ & 14 & 1 \\
\hline $115-706 C-5 R-2,102-105$ & $\mathrm{Pl}, \mathrm{Px}, \mathrm{Gl}, \mathrm{Ol}, \mathrm{Ox}$ & 17 & 1 \\
\hline $115-706 C-5 R-3,44-48$ & $\mathrm{Pl}, \mathrm{Gl}, \mathrm{Ol}$ & 19 & i \\
\hline $115-706 \mathrm{C}-6 \mathrm{R}-1,46-50$ & $\mathrm{Pl}, \mathrm{Px}$ & 20 & 1 \\
\hline $115-706 C-8 R-2,43-45$ & $\mathrm{Pl}, \mathrm{Px}, \mathrm{Ox}$ & 28 & 2 \\
\hline $115-706 C-9 R-2,36-38$ & $\mathrm{Pl}, \mathrm{Px}$ & 32 & 3 \\
\hline $115-707 C-22 R-1,94-95$ & $\mathrm{Pl}, \mathrm{Px}, \mathrm{Ox}$ & 1 & 1 \\
\hline $115-707 C-22 R-2,37-38$ & $\mathrm{Pl}, \mathrm{Px}$ & 1 & 1 \\
\hline $115-707 C-23 R-1,24-25$ & $\mathrm{Pl}, \mathrm{Px}, \mathrm{Ox}$ & 2 & 2 \\
\hline $115-707 C-23 R-1,65-66$ & $\mathrm{Pl}, \mathrm{Px}$ & 2 & 2 \\
\hline $115-707 C-23 R-3,137-140$ & $\mathrm{Pl}, \mathrm{Px}$ & 3 & 2 \\
\hline $115-707 C-25 R-3,0-1$ & $\mathrm{Pl}, \mathrm{Px}$ & 4 & 3 \\
\hline $115-707 C-26 R-2,126-128$ & $\mathrm{Pl}, \mathrm{Px}, \mathrm{Ox}$ & 4 & 3 \\
\hline $115-707 \mathrm{C}-28 \mathrm{R}-1,27-29$ & $\mathrm{Pl}$ & 5 & 4 \\
\hline $115-707 C-28 R-3,48-50$ & $\mathrm{Pl}, \mathrm{Px}, \mathrm{Ox}$ & 5 & 4 \\
\hline $115-713$ A-13R-3, $16-20$ & $\mathrm{Pl}, \mathrm{Px}$ & 2 & 1 \\
\hline $115-713 \mathrm{~A}-15 \mathrm{R}-4,44-46$ & $\mathrm{PI}, \mathrm{Px}, \mathrm{Ox}$ & 3 & i \\
\hline $115-713 A-15 R-4,143-145$ & $\mathrm{Pl}, \mathrm{Px}$ & 4 & 2 \\
\hline $115-713 A-15 R-5,3-7$ & PI, Px, GI & 5 & 2 \\
\hline $115-713 \mathrm{~A}-17 \mathrm{R}-2,41-44$ & $\mathrm{Pl}, \mathrm{Gl}$ & - & a_- \\
\hline $115-713 \mathrm{~A}-19 \mathrm{R}-1,15-20$ & Gl, OI & 8 & 3 \\
\hline $115-713 \mathrm{~A}-19 \mathrm{R}-1,116-118$ & $\mathrm{Pl}, \mathrm{Px}$ & 10 & 3 \\
\hline $115-713 \mathrm{~A}-20 \mathrm{R}-2,37-39$ & $\mathrm{Gl}, \mathrm{Ol}$ & 12 & 3 \\
\hline $115-713$ A-20R-2, 89-91 & $\mathrm{Gl}, \mathrm{Ol}$ & 13 & 3 \\
\hline $115-713 \mathrm{~A}-20 \mathrm{R}-3,64-66$ & Gl, Ol & 15 & 3 \\
\hline $115-713$ A-20R-5, 98-99 & Gl, Ol & 21 & 3 \\
\hline $115-713 A-20 R-6,22-44$ & $\mathrm{Gl}, \mathrm{Ol}$ & 23 & 3 \\
\hline $115-713$ A-21R-2, $130-132$ & $\mathrm{Gl}$ & 32 & 3 \\
\hline $115-715 \mathrm{~A}-23 \mathrm{R}-2,26-28$ & $\mathrm{Pl}, \mathrm{Px}$ & 4 & 1 \\
\hline $115-715 \mathrm{~A}-23 \mathrm{R}-3,44-46$ & $\mathrm{Pl}, \mathrm{Px}, \mathrm{Ox}$ & $7 a$ & 1 \\
\hline $115-715 A-25 R-3,25-27$ & $\mathrm{Pl}, \mathrm{Px}, \mathrm{Ox}$ & 9 & 2 \\
\hline $115-715 A-25 R-6,37-38$ & $\mathrm{Pl}, \mathrm{Px}$ & 10 & 2 \\
\hline $115-715$ A-29R-1, 1-2 & $\mathrm{Pl}, \mathrm{Px}$ & 12 & 3 \\
\hline $115-715 A-29 R-1,116-118$ & $\mathrm{Pl}, \mathrm{Px}$ & 13 & 3 \\
\hline $115-715 \mathrm{~A}-30 \mathrm{R}-3,40-41$ & $\mathrm{PI}, \mathrm{Px}, \mathrm{OI}, \mathrm{Ox}$ & 16 & 3 \\
\hline 115-715A-31R-2, 94-95 & $\mathrm{PI}, \mathrm{Px}$ & 21 & 3 \\
\hline
\end{tabular}

Note: $\mathrm{PI}=$ plagioclase, $\mathrm{Px}=$ pyroxene, $\mathrm{Gl}=$ glass, $\mathrm{Ol}=$ olivine, and $\mathrm{Ox}$ = oxide.

a Volcanic ash in sediment between Units 2 and 3. 